\title{
LOS CONCEPTOS JURÍDICOS INDETERMINADOS EN EL LENGUAJE CONSTITUCIONAL
}

JOSÉ IGNACIO MARTÍNEZ ESTAY 
SUMARIO

I. INTRODUCCIÓN: LOS CONCEPTOS JURÍDICOS INDETERMINADOS. II. CONCEPTOS JURÍDICOS INDETERMINADOS EN ALGUNOS SISTEMAS CONSTITUCIONALES: ESTADOS UNIDOS, ALEMANIA, ESPAÑA Y CHILE. III. DIFICULTADES QUE CONLLEVA EL USO DE CONCEPTOS INDETERMINADOS EN EL DERECHO CONSTITUCIONAL. IV. UN NUEVO PROBLEMA: DE CONCEPTOS DETERMINADOS A CONCEPTOS CONTROVERTIDOS. V. CONCLUSIONES. 


\title{
LOS CONCEPTOS JURÍDICOS INDETERMINADOS EN EL LENGUAJE CONSTITUCIONAL ${ }^{1}$
}

\author{
JOSÉ IGNACIO MARTÍNEZ ESTAY²
}

\section{INTRODUCCIÓN: LOS CONCEPTOS JURÍDICOS INDETERMINADOS}

Como ocurre en general con el lenguaje, en el ámbito jurídico-normativo los términos que se utilicen pueden muchas veces ser interpretados de manera diversa, y hasta contradictoria. Es lo propio de aquello que Hart denominó «la textura abierta del derecho» ${ }^{3}$, que se presenta de distintas formas, según la mayor o menor precisión de los conceptos que se utilicen, o lo que es lo mismo, conforme a la mayor o menor amplitud de su significado. Tradicionalmente se habla de conceptos determinados para referirse a los que poseerían mayores grados de determinación y especificidad, y de indeterminados para señalar a aquéllos cuya formulación resulta

${ }^{1}$ Este trabajo es parte del proyecto Fondecyt N. ${ }^{\circ} 1150869$ «Los conceptos jurídicos indeterminados de la Constitución chilena en la jurisprudencia del Tribunal Constitucional: Significado, contenidos y alcances». Agradezco muy especialmente al profesor de Derecho Constitucional de la Universidad Diego Portales, Javier Couso Salas, co-investigador de este proyecto, por las agudas sugerencias y comentarios efectuados al borrador de este trabajo, así como sus aportes de la bibliografía relativa al uso de conceptos indeterminados en el sistema constitucional norteamericano. Agradezco también de manera especial al profesor Rainer Arnold, de la Universidad de Regensburg, por su ayuda en la preparación del apartado sobre los conceptos indeterminados en el sistema constitucional alemán.

2 Profesor de Derecho Constitucional y Administrativo, Universidad de los Andes, Chile. Av. Monseñor Alvaro del Portillo 12.455, Las Condes, Santiago, Chile. E-mail: jimartinez@uandes.cl. Num. Id. ORCID 0000-0001-8017-4470. Investigador responsable proyecto Fondecyt N. ${ }^{\circ} 1150869$.

${ }^{3}$ Hart, H.L.A. (2004). El concepto de Derecho, Buenos Aires, Abeledo-Perrot, reimpresión 2.a ed., 155-191. 
más abstracta e imprecisa ${ }^{4}$. Estos últimos entregarían más bien una orientación general para la actuación de los poderes públicos, mediante la fijación de algunos estándares mínimos, dejando un amplio espacio para su concreción y delimitación a otros órganos. A este respecto es importante destacar que, como señala Comanducci, la mayor imprecisión de algún concepto no es necesariamente un problema de «incapacidad técnica» o «de acuerdo político», sino que «a veces se trata de una elección consciente, que tiende a delegar en otras instancias normativas el poder reducir la indeterminación» ${ }^{5}$.

Desde ese punto de vista, puede señalarse que la expresión conceptos indeterminados alude a una cierta intención de introducir expresiones imprecisas en una norma. En efecto, y como explica Ara Pinilla, «la alusión a los conceptos jurídicos indeterminados está poniendo de relieve la voluntad del emisor del lenguaje jurídico de mantener indeterminado a priori su contenido semántico, a diferencia de lo que sucede con el resto de los conceptos que pueblan los enunciados jurídicos, los cuales, sea cual sea el modo en que son asumidos de hecho por sus destinatarios, pretende su emisor que resulten perfectamente determinados» ${ }^{6}$.

En cuanto a su estructura, Cassagne destaca que, por regla general, los conceptos indeterminados «no admiten más que una solución justa», y poseen una estructura compleja, compuesta por «a) un núcleo fijo o zona de certeza positiva, integrado por elementos precisos; b) un «halo conceptual» o zona de incertidumbre, de menor precisión, es decir, donde reina cierta ambigüedad; y, por último, c) una zona de certeza negativa, que excluye totalmente la posibilidad de una solución justa» ${ }^{7}$, todo lo cual debe ser especialmente considerado por el órgano encargado de precisar el correspondiente concepto.

Sin embargo, y más allá de la intención del productor de la norma, debe tenerse presente que en principio todo precepto jurídico tiene una cierta indeterminación, ya que su formulación involucra en buena medida algún grado de abstracción. En palabras de Hart, ello implica asumir que en el Derecho existen «áreas de conducta don-

${ }^{4}$ Ortega Gutiérrez, D. (2009). Los conceptos jurídicos indeterminados en la jurisprudencia española, Madrid, Dykinson,18. García Salgado destaca que en España la doctrina utiliza como sinónimos las expresiones «conceptos vagos», «conceptos jurídicos indeterminados» y «cláusulas generales», y destaca que en Alemania suele distinguirse entre «cláusulas generales y conceptos indeterminados, aunque no hay acuerdo respecto de cuáles sean los criterios que los diferencian y dependan en buena medida de los presupuestos y necesidades de cada investigación». García Salgado, M.J. (2003). «Determinar lo indeterminado: sobre cláusulas generales y los problemas que plantean». Anuario de Filosofía del Derecho N. . 20, 106-107. Guiloff prefiere hablar de «legislación no transitiva» para referirse a los preceptos legales indeterminados; en Guiloff Titiun, M. (2012). «Operativizando la relación ley-reglamento: una propuesta de redefinición del rol de la reserva legal». Revista de Derecho, Vol. XXV, N. ${ }^{\circ} 1130,129$ y 134.

${ }^{5}$ Comanducci, P. (1998). «Principios jurídicos e indeterminación del Derecho». Doxa 21, II, 102.

${ }^{6}$ Ara Pinilla, I. (2004). «Presupuestos y posibilidades de la doctrina de los conceptos jurídicos indeterminados». Anuario de filosofía del derecho, N. ${ }^{\circ} 21,111$.

7 Cassagne, J.C. (2016). El principio de legalidad y el control judicial de la discrecionalidad administrativa, Montevideo-Buenos Aires, B de F., 249. 
de mucho debe dejarse para que sea desarrollado por los tribunales o por los funcionarios que procuran hallar un compromiso, a la luz de las circunstancias, entre los intereses en conflicto, cuyo peso varía de caso en caso» ${ }^{8}$. Por eso, Ara Pinilla plantea que a veces pareciera creerse que los conceptos indeterminados tendrían como característica propia, una indeterminación que sólo estaría presente en ellos, y no en los demás conceptos normativos? .

En cualquier caso, lo cierto es que todo precepto, incluya o no conceptos indeterminados, debe ser interpretado ${ }^{10}$, lo que hace necesaria su concreción para efectos de su aplicación, tarea que no resulta fácil, en atención a la «textura abierta del lenguaje humano, de la inmensa e impredecible variedad de comportamientos humanos y, tal como Hart lo señala, de la relativa indefinición del propósito legislativo» ${ }^{11}$. Se trata por tanto de un problema inherente al Derecho, y en particular de las normas constitucionales, legales o administrativas, cuyo sentido y alcance debe ser determinado para efectos de su adecuada aplicación. Para tal fin, el intérprete debería considerar primeramente el significado habitual de los términos que se utilizan en la formulación normativa, así como «toda una serie de convenciones interpretativas - ...... - cuyo contenido está determinado por las prácticas de los operadores jurídicos correspondientes» ${ }^{12}$.

Sin perjuicio de todo lo anterior, en la literatura jurídica hay autores que plantean las ventajas del uso de conceptos indeterminados por las constituciones, al punto que «[L]a imprecisión de los términos jurídicos ha pasado de ser considerada un defecto del derecho y un mal endémico que no tiene solución, a valorarse como un aspecto

${ }^{8}$ Hart, H.L.A. (2004). El concepto de Derecho, Buenos Aires, Abeledo-Perrot, reimpresión 2. a ed., 168.

9 En concreto Ara Pinilla sostiene que «[S]e supone así que cuando nos encontramos frente a uno de los denominados conceptos jurídicos indeterminados, debemos efectuar un esfuerzo adicional al normalmente exigible, o en su caso apelar a una instancia superior, con vistas a solucionar la indeterminación semántica, esto es, a hacer que el concepto en cuestión resulte convenientemente determinado, siquiera se produzca la apuntada solución en un momento lógicamente ulterior a la emisión del enunciado en cuestión. En este sentido, el reconocimiento de la referida indeterminación semántica por parte de los distintos operadores jurídicos no hace más que legitimar en forma indirecta al resto del lenguaje jurídico, como si éste estuviera en general desprovisto de problemas de determinación conceptual, de manera que la presencia de conceptos jurídicos indeterminados constituyera la excepción puntual (las excepciones puntuales) a la regla general de la claridad de los textos jurídicos y del significado unívoco de los términos que los integran». Ara Pinilla, I. (2004). «Presupuestos y posibilidades de la doctrina de los conceptos jurídicos indeterminados». Anuario de filosofía del derecho, N. ${ }^{\circ} 21,108$.

${ }^{10}$ Como plantea Massini, interpretar supone «descubrir, en un enunciado normativo determinado, cuál es la norma jurídica que con él se significa, i. e. la norma-proposición lógica adecuada a la resolución de un caso práctico, en especial práctico-jurídico». Massini Correa, C. I. (2010). «Iusnaturalismo e interpretación jurídica», Díkaion, Año 24, Vol. 19 Núm. 2, 404-405.

11 Yowell, P. (2012). «Legislación, common law, y la virtud de la claridad». Revista Chilena de Derecho, vol. 39, N. $2,483$.

12 Bayón, J. C. (2000). «Derrotabilidad, indeterminación del derecho y positivismo jurídico». Isonomía N. $13,103$. 
esencial del mismo al que el legislador no debe renunciar $»^{13}$. Así por ejemplo, Montalvo señala que el uso de estos conceptos permite que las constituciones centren su atención en lo fundamental, y que en aquello que no lo es, se confíe en las soluciones que proveerá el ordenamiento jurídico. De esta manera, cuando la Constitución regula «sólo aquello que parece objetivamente importante y requiere determinación, queda abierta una posible vía para que entren en escena figuras que, voluntariamente o no, nunca llegaron a ser definidas completamente, dando por hecho que la aplicación de las normas al entramado social generaría soluciones por sí solas para ese tipo de situaciones. Es decir, la Constitución no se limita a dejar abierto, sino que establece, con carácter vinculante, lo que no debe quedar abierto, como son los fundamentos del orden de la comunidad, creando un recinto fuerte de aquello que debe considerarse indispensable» ${ }^{14}$.

A su vez, Arnold destaca que en el lenguaje constitucional se suele acudir a este tipo de conceptos al menos por dos razones. En primer lugar, porque se trata de términos abiertos, susceptibles de adaptarse en el tiempo, lo que a su juicio contribuye a la permanencia y estabilidad del sistema constitucional ${ }^{15}$. Y la segunda razón, derivada de la anterior, radica en que a través de dichos conceptos la Constitución se alinearía de mejor manera con la idea moderna de Estado de Derecho, que, junto a la separación de poderes, conlleva también la moderación de la intervención del poder público en la esfera de los derechos y libertades individuales, así como la garantía efectiva de éstos ${ }^{16}$.

A esas dos razones podría agregarse una tercera, planteada por García Salgado, para quien la incorporación de cláusulas abiertas o indeterminadas es a veces una forma de resolver la tensión que se produce respecto de «cuestiones sobre las que es difícil alcanzar un acuerdo (porque las posturas están muy enfrentadas o porque hay muchos intereses inconmensurables y, por tanto, inconciliables en juego)» ${ }^{17}$. Así, mediante la introducción de un concepto indeterminado se buscaría que «sea el juez quien en cada momento lo precise» ${ }^{18}$. Pero como se comprenderá, esta opción supone asumir el riesgo propio de un indeseado activismo judicial, que puede llevar a que los

13 García Salgado, M.J. (2003). «Determinar lo indeterminado: sobre cláusulas generales y los problemas que plantean». Anuario de Filosofía del Derecho N. ${ }^{\circ} 20,113$.

${ }_{14}$ Montalvo Abiol, J.C. (2010). «Concepto de orden público en las democracias contemporáneas». Revista Jurídica Universidad Autónoma de Madrid, N. ${ }^{\circ 22} 205$.

15 Arnold, R. (2001). «Reflexions sur l'argumentation juridique ein droit constitutionnel allemand». Otto Pfersmann/Gérard Timsit (Hrsg.), Raisonnement juridique et interprétation, Publications de la Sorbonne, Paris, 49 y ss.

${ }^{16}$ Ibid.

${ }_{17}$ García Salgado, M.J. (2003): «Determinar lo indeterminado: sobre cláusulas generales y los problemas que plantean». Anuario de Filosofía del Derecho N. ${ }^{\circ}$ 20, 127. Por su parte Segura Ortega sostiene a este respecto que en los sistemas constitucionales y democráticos existen normas que «son redactadas de una manera intencionadamente vaga y ambigua porque son el producto de un proceso de negociación que pretende hallar el acuerdo entre ideologías diferentes», en Segura Ortega, M. (2013). «Problemas interpretativos e indeterminación del Derecho». Dereito, vol. 22, 674.

${ }_{18}$ García Salgado, M.J. (2003): «Determinar lo indeterminado: sobre cláusulas generales y los problemas que plantean». Anuario de Filosofía del Derecho N. ${ }^{\circ} 20,127$. 
jueces impongan sus propias convicciones personales, en temas en los que justamente no existe consenso, o hay visiones diversas y legítimas, bajo la excusa de su deber de precisar conceptos abiertos.

En cualquier caso, es un hecho que las constituciones incorporan en sus textos conceptos indeterminados, aunque puede variar tanto la cantidad como el tipo de conceptos que utilice cada una de ellas. A continuación, se revisará brevemente el uso de esta clase de expresiones en cuatro sistemas constitucionales. En primer lugar, el norteamericano, no sólo por la relevancia del constitucionalismo de Estados Unidos, fundado en la primera Constitución codificada, sino porque además ésta es un texto más bien breve, y por ende en principio más preciso, a pesar de lo cual la doctrina, la Corte Suprema y el Congreso, han identificado en él conceptos indeterminados. Algunos de éstos han recibido interpretaciones que en principio podrían distar de su sentido original, y que han conducido por ejemplo a la doctrina del interés público, la del poder de policía y la de los derechos implícitos, de amplio impacto en la historia constitucional norteamericana, y que también han sido recogidas, al menos en parte, por la doctrina y la jurisprudencia de terceros países.

En seguida se revisará el uso de conceptos indeterminados en la Constitución de Alemania, atendida la relevancia e impacto del modelo constitucional alemán en buena parte de Europa y de Latinoamérica. La influencia del constitucionalismo alemán abarca también a conceptos abiertos, incorporados en la Ley Fundamental, y desarrollados ampliamente por la jurisprudencia del Tribunal Constitucional. Entre éstos destaca de manera especial el de dignidad, acogido posteriormente por diversas constituciones, así como el desarrollo jurisprudencial de la noción de derechos fundamentales entendidos como valores, doctrina que ha impactado también en muchos otros modelos constitucionales europeos y latinoamericanos ${ }^{19}$.

Luego se revisará la incorporación de conceptos indeterminados en la Constitución española. De más está destacar la importancia de este texto, símbolo del constitucionalismo democrático de finales de la década de los setenta del siglo pasado, corriente que surge a partir de la caída de regímenes dictatoriales europeos y latinoamericanos. La Constitución española y su interpretación jurisprudencial y doctrinaria, ha sido seguida de manera especial en Latinoamérica. Por eso parece interesante revisar qué conceptos abiertos utiliza, y, en términos generales, cómo han sido entendidos jurisprudencial y doctrinariamente.

Finalmente, se analizarán los conceptos indeterminados en la Constitución de Chile. Este texto se inspiró en parte en el modelo constitucional alemán, tanto en su origen como en su desarrollo normativo, jurisprudencial y doctrinario. No obstante, el constitucionalismo chileno también ha recibido una influencia similar del español, y, en menor medida, del norteamericano, en particular en algunos sectores doctrinarios.

19 La influencia del constitucionalismo alemán se ve por ejemplo en los sistemas constitucionales español y chileno, en donde la doctrina del Tribunal Constitucional Federal, que entiende a los derechos fundamentales como valores positivizados, ha sido seguida por los altos tribunales de cada uno de estos países. Ver ejemplos en nota al pie 98. 


\section{CONCEPTOS JURÍDICOS INDETERMINADOS EN ALGUNOS SISTEMAS CONSTITUCIONALES: ESTADOS UNIDOS, ALEMANIA, ESPAÑA Y CHILE}

\section{Conceptos indeterminados en el sistema constitucional norteamericano}

La Constitución de los Estados Unidos es breve $\mathrm{e}^{20}$, y por ello poco prolífica en el uso de conceptos indeterminados, los que con el tiempo han ido siendo interpretados por la Corte Suprema y por otros órganos, como el Senado. En concreto, tienen este carácter el «debido proceso», la «justa compensación»(V Enmienda), las «fianzas y multas excesivas», los «castigos crueles» (VIII Enmienda) y la «igualdad» (Enmienda XIV, sección 1).

No obstante, la interpretación de estos conceptos por la Corte Suprema es más bien reciente. De hecho, a comienzos del siglo xx autores como Pound ${ }^{21}$ y Brandeis ${ }^{22}$ criticaban con fuerza la interpretación «formalista» de la Corte Suprema norteamericana, por apegarse excesivamente a la literalidad de la Constitución, sin abrirse a «fines sociales» que a su juicio podían promoverse a partir de nociones constitucionales implícitas como el «interés público» o el «poder de policía». Para ellos, estos conceptos permitían promover fines sociales más amplios, sin importar si estos cambios afectaban la libertad de contrato y el derecho de propiedad. Esta doctrina dio origen al denominado «realismo constitucional», impulsado desde la academia con el objeto de incorporar a la Constitución nociones que, si bien no tenían asidero expreso en su texto, podían extraerse a partir de conceptos jurídicos indeterminados, los que permiten una más amplia interpretación. A partir de aquel momento se produce un evidente cambio, al punto que autores como Epstein y Dixon destacan que la Corte Suprema norteamericana ha hecho una generosa interpretación de determinadas cláusulas, como por ejemplo las de debido proceso e igualdad ante la ley ${ }^{23}$.

Breyer $^{24}$ afirma además que la Constitución utiliza un lenguaje inespecífico en temáticas como la libertad de expresión, el federalismo, la privacidad y la igualdad, lo que en su opinión ha permitido una interpretación extensiva para afrontar la reso-

${ }^{20}$ La Constitución norteamericana es un buen ejemplo de aquello que sugiere Wheare, en cuanto a que las Constituciones deben contener lo mínimo, y este mínimo debe traducirse en normas jurídicas, no en principios o programas. Ver Wheare, K.C. (1975): Las constituciones modernas, Barcelona, Labor, 38.

${ }^{21}$ Pound, R. (1907). «The Need of a Sociological Jurisprudence». The Grenn Bag, Vol. 19, 607615. Pound, R. (1908a): «Mechanical Jurisprudence». Columbia Law Review, vol. 8, 605-623. Pound, R. (1908b): «Liberty of Contract». Yale Law Journal, vol. 18, 454-487.

22 Brandeis, L.D (1916). "The living Law». Illinois Law Review, Vol. X, N. . 7, 461-471.

${ }^{23}$ Esta temática ha sido abordada con precisión en dos obras de estos autores, de consulta obligada: Epstein, R. A. (2006). How progressives rewrote the Constitution, N. York, Cato Institute. Dixon, R. (2009). «Updating constitutional rules». Supreme Court Review, 319-346.

${ }^{24}$ Breyer, S. (2002). «Our democratic Constitution». New York University Law Review, Vol 77, Number 2, 250-265, 268. 
lución de problemas contemporáneos, que no existían al momento de redactarse la carta fundamental. Entre aquéllos se cuenta, por ejemplo, la regulación del financiamiento de campañas electorales, cuestión que debía sortear los límites impuestos por la I Enmienda a propósito de la libertad de expresión, lo que se lograba si se consideraba que la protección del sistema democrático era inherente a esa Enmienda.

A su vez, la interpretación amplia de los principios constitucionales del federalismo, conducen a las nociones de libertad activa y negativa, que implícitamente son «facilitadores» del sistema democrático. Asimismo, a partir de la IV Enmienda y de una interpretación extensiva de la protección de la privacidad, se ha logrado abarcar y regular ámbitos propios del desarrollo tecnológico (comunicaciones, imágenes, etc.), que por ende no estaban presentes en los orígenes de la Constitución norteamericana, mediante la incorporación del concepto «interés público», que estaría implícito en esta Enmienda ${ }^{25}$.

Finalmente, el principio de igualdad consagrado en la XV Enmienda, no sólo ha servido como mandato de interdicción de la discriminación arbitraria en el ejercicio del derecho a sufragio por parte de minorías raciales. En efecto, de manera implícita ha hecho posible también la adopción de medidas de discriminación positiva en favor de éstas, con el fin de que la democracia sea efectiva.

Por su parte, Epstein resalta también el rol de concepto indeterminado de la cláusula relativa al comercio interestatal, cuya extensa interpretación hizo posible implementar y llevar a cabo las políticas del New Deal, a pesar de que en su opinión esa interpretación no era acorde ni al texto ni a la historia de la norma, y por ende a partir de ella no podía reconocerse competencia al Congreso Federal para regular la economía ${ }^{26}$.

La doctrina ha destacado también que la Corte Suprema ha ido «descubriendo» otros conceptos indeterminados, que surgirían a partir de una interpretación extensiva de la novena enmienda. Este sería el caso de los denominados «derechos no explícitos» o «derechos implícitos» de la esfera moral, como la «vida privada» y la «dignidad humana», cuya peculiaridad radica en la amplitud con que los ha definido la Corte. La amplitud interpretativa de la Corte se ve reflejada por ejemplo en Roe $v$. Wade, sentencia en la que, a partir del derecho a la vida privada, reconoció el derecho de la mujer a abortar, el que obviamente no está incluido expresamente en el texto de la Constitución, dando origen a una polémica que se extiende hasta hoy ${ }^{27}$.

${ }^{25}$ Como Breyer, Reinert sostiene también que el interés público es un concepto no contemplado expresamente en la Constitución, y que ha sido desarrollado por la jurisprudencia a partir de la IV Enmienda y del derecho a la privacidad. Ver Reinert, A.A. (2010). «Public Interest(S) and Fourth Amendment Enforcement». University of Illinois Law Review, N. ${ }^{\circ}$ 5, 1462-1504.

${ }^{26}$ Epstein, R.A. (2006). How progressives rewrote the Constitution, N. York, Cato Institute, 72.

${ }^{27}$ Sobre la posición de la Corte en estas materias puede consultarse Barnett, R. (1988). «Reconceiving the Ninth Amendment». Cornell Law Review, vol. 74, 1-42. Barnett, R. (2006). «Who is afraid of unenumerated rights?». University of Pennsylvania Journal of Constitutional Law, vol. 9, 2-21. Una visión crítica de la posición de la Corte puede verse en Legarre, S. (2004). Poder de policía y moralidad pública, Buenos Aires, Ábaco-De Palma 
Asimismo, los conceptos indeterminados han permitido también la expansión de las atribuciones de un órgano como el Senado. Al respecto, Halperin destaca que la interpretación de algunas cláusulas ha hecho posible fortalecer el rol de esta cámara, a propósito de la designación de determinados $\operatorname{cargos}^{28}$.

Sin embargo, autores como Graglia han llamado la atención acerca de que estas cláusulas abiertas presentan el riesgo de transformarse en una especie de «cheque en blanco», que habilitaría a la Corte Suprema a decidir centralizadamente sobre políticas públicas $^{29}$. Esto conduciría a uno de los riesgos propios del activismo judicial, a saber, que la interpretación de la Constitución se haga conforme a los valores que detenta el intérprete, según lo han advertido, por ejemplo, Chemerinsky ${ }^{30}$, o Scalia y Gutmann ${ }^{31}$.

\section{Conceptos indeterminados en el sistema constitucional alemán}

A diferencia de la norteamericana, en la Constitución alemana hay un más abundante uso de conceptos indeterminados. Unos están vinculados al ser humano y sus derechos. Es el caso de «la dignidad humana» (art. 1.1); el «libre desarrollo de la personalidad» (art. 2.1); el «honor personal» (art. 5.2); el «abuso de derechos y libertades» (art. 18). Otros están relacionados con los fines de la comunidad política, como las «necesidades vitales» de la población civil (art. 12.a.3); el «peligro inminente» (art. 13); la «seguridad y el orden públicos» (art. 13.7); el «bien común» (art. 14); los «intereses de la comunidad y de los afectados» (art. 14.3); el «interés pedagógico especial» (art. 7.5); el «contenido esencial» de un derecho fundamental (art. 19.2); el «estado social» (art. 20, 23, 28); los «servicios adecuados y suficientes» (art. 87.1), y el «equilibrio global de la economía» (art. 104.b.1; art.109.2).

La doctrina alemana ha sostenido que estos conceptos constitucionales indeterminados se vinculan con los criterios específicos de interpretación de la Constitución, y con el carácter dinámico de ésta («instrumento vivo») que debe adaptarse, a los cambios sociales fundamentales ${ }^{32}$. Por su parte, el Tribunal Constitucional federal ha analizado de manera

${ }^{28}$ Halperin, M (1988). «Constitutional Review and Open-Ended Clauses». Harvard Journal of Law E Public Policy, Vol. 11, ISSUE 1, 97.

${ }_{29}$ Graglia, L.A. (1988). «The open-ended clauses of the Constitution». Harvard J. L. E Public Policy, VOL. 11, ISSUE 1, 88, 90 y 91.

${ }^{30}$ Chemerinsky, E. (1987). Interpreting the Constitution, N. York, Praeger.

31 Scalia, A. y Gutmann, A. (1998). A Matter of Interpretation: Federal Courts and the Law, Princeton, Princeton U. Press.

32 A modo de ejemplo ver Müller, F (1966). Normstruktur und Normativität, Berlin, Duncker \& Humblot.; Böckenförde, E-W. (1976). Die Methoden der Verfassungsinterpretation - Bestandsaufnahme und Kritik, Neue Juristische Wochenschrift (NJW); Larenz, K. (1991). Methodenlebre der Rechtswissenschaft, 6a ed; Arnold, R. (2001). «Reflexions sur l'argumentation juridique ein droit constitutionnel allemand». Otto Pfersmann/Gérard Timsit (Hrsg.), Raisonnement juridique et interprétation, Publications de la Sorbonne, Paris, 49-86; Larenz, K. y Canaris, C-W. (2008). Methodenlehre der Rechtswissenschaft, Berlin-Heidelberg, Springer.; Arnold, R. (2009). «Europäische Verfassungsprinzipien als transnationales Phänomen». Manssen/Jachmann/ Gröpl (Hrsg.), Nach geltendem Verfassungsrecht, Festschrift für Udo Steiner, Stuttgart, 14-29. 
especial algunos de esos términos, con el objetivo de determinar y precisar el sentido que debe dárseles a expresiones como «libre desarrollo de la personalidad $»^{33} \mathrm{o}$ «peligro» ${ }^{34}$. No obstante, la jurisprudencia más relevante en estas materias es probablemente la relativa al concepto «dignidad» ${ }^{35}$, cuestión que ha sido también objeto preferente de estudio por la doctrina $^{36}$. La razón de esto es el preponderante lugar que dicha expresión ocupa en la Constitución alemana, formal y materialmente hablando, ya que su artículo 1.1 declara que es «intangible», y que su respeto y protección «es obligación de todo poder público» ${ }^{37}$.

Pero además, en Alemania la temática de los conceptos jurídicos indeterminados se vincula directamente con la concepción de los derechos fundamentales entendidos como un orden objetivo de valores. Esta doctrina tiene su origen en la doctrina emanada del Tribunal Constitucional federal en el conocido caso Lüth$^{38}$. Su aplicación puede permitir transformar conceptos indeterminados, vinculados con derechos fundamentales, en instrumentos primarios del desarrollo jurídico y social del ordenamiento constitucional ${ }^{39}$, y en parámetros de control de constitucionalidad ${ }^{40}$. Esto haría posible la adaptación a cada momento histórico de aquellos derechos, así como de los valores que éstos envuelven.

\section{Conceptos indeterminados en el sistema constitucional español}

En la Constitución española la presencia de conceptos indeterminados es bastante amplia, y es consecuencia de los preceptos que se refieren tanto a la persona y sus

33 Por ejemplo sentencias BVerfGE 6, 389, 433; BVerfGE 27, 344, 351; BVerfGE 54, 148, 153; BVerfGE 65, 1, 43; BVerfGE 78, 77, 84; BVerfGE 113, 29, 46.

${ }^{34}$ Por ejemplo sentencias BVerfGE 100, 313, 376, 383-384; BVerfGE 90, 145, 173; BVerfGE 109, 279, 335, 349, 353.

35 Por ejemplo sentencias BVerfGE 4, 7, 15-16; BVerfGE 6, 32, 36; BVerfGE 109, 133, 149; BVerfGE 27, 1,7; BVerfGE 125, 175, 223-226; BVerfGE 115, 1181.

36 Por ejemplo, Spaemann, R. (1988). «Sobre el concepto de dignidad humana». Persona y Derecho 19, 13-33; Enders, C. (1997). Die Menschenwürde in der Verfassungsordnung: Zur Dogmatik des Art. 1 GG, Mohr Siebeck, TÜbingen.; Starck, C. (2005). «Introducción a la dignidad humana en el derecho alemán». Anuario Iberoamericano de Justicia Constitucional, núm. 9, 489-497; Luther, J. (2007). «Razonabilidad y dignidad humana». Revista de derecho constitucional europeo, N. ${ }^{\circ}$ 7, 295-326; von Münch, I. (2009). «La dignidad del hombre en el derecho constitucional alemán». Foro, Nueva época, núm. 9, 109-123.

37 Un interesante análisis crítico sobre la forma en que el Tribunal Constitucional alemán ha entendido y utilizado el concepto dignidad humana, puede consultarse en Covarrubias, I. (2014b). «¿Puede la dignidad humana ser un principio comúnmente compartido en materia de adjudicación constitucional?». Actualidad Jurídica, N. ${ }^{\circ} 29,153$ y ss.

38 Sentencia BVerfGE 7, 198.

39 Ver Hesse, K. (1995). Derecho Constitucional y Derecho Privado, Madrid, Civitas, trabajo en que se analiza la influencia de los derechos fundamentales, especialmente en el Derecho Civil, lo que ha conducido en Alemania a una relación y complementación entre Derecho Constitucional y Derecho Privado; También Hesse, K. (2011). Escritos de Derecho Constitucional, Madrid, Fundación Coloquio Jurídico Europeo/ Centro de Estudios Políticos y Constitucionales, 156-164, trabajo en el que Hesse se refiere al carácter objetivo de los derechos fundamentales, y a las consecuencias derivadas de esta característica.

40 Bachof, O. (1985). Jueces y Constitución, Madrid, Civitas, 42-43. 
derechos, a los objetivos y fines del Estado, así como a la noción de Estado Social y su relación con los derechos sociales, y con la forma de Estado.

En lo que respecta a la persona y sus derechos, la Constitución española contempla varios conceptos indeterminados. Entre otros pueden destacarse la «interdicción de la arbitrariedad» (art. 9.3); «la dignidad de la persona» (art. 10.1); las «libertades públicas» (art. 13.1); el «orden público» (arts. 16.1; 21.2); el «plazo máximo de duración» y el «plazo de tiempo razonable» (art. 17.4); el «honor», la «intimidad personal y familiar» y la «propia imagen» (art. 18.1); la «tutela judicial efectiva» (art. 24.1); el «contenido esencial» de los derechos y libertades (art. 53.1).

Pero también hay otros que se relacionan con los objetivos y fines de la comunidad política, como «la libertad, la justicia, la igualdad y el pluralismo político» como «valores superiores» del ordenamiento jurídico (art. 1.1); el «orden político» y la «paz social» (art. 10.1); los «grupos sociales y políticos significativos» (art. 20.3); los «principios democráticos de convivencia» (art. 27.2); el «servicio esencial» (arts. 28.2, 37.2 y 128.2); la «utilidad pública o interés social» (art. 33.3); el «interés general» (art. 34.1); la «extraordinaria y urgente necesidad» (art. 86); los «intereses generales» (art. 103.1); la «seguridad y defensa del Estado» (art. 105.b).

No obstante, también hay numerosos conceptos abiertos vinculados a la noción de Estado Social y derechos sociales. Entre éstos se cuentan expresiones como «intereses económicos y sociales» (art. 7); «seguridad social» (art. 25.2; art. 41; 129.1; 149.1.17); «capacidad económica» (art. 31.1); "protección social, económica y jurídica de la familia» (art. 39.1); "progreso social y económico» (art. 40.1); «medio ambiente» (art. 45); «solidaridad colectiva» (art. 45.2); "patrimonio histórico, cultural y artístico» (art. 46); «vivienda digna y adecuada» (art. 47); «desarrollo político, social, económico y cultural» (art. 48); «política de previsión, tratamiento, rehabilitación e integración de los disminuidos físicos, sensoriales y psíquicos» (art. 49); «pensiones adecuadas», "problemas específicos de salud, vivienda, cultura y ocio» (art. 50); «la seguridad, la salud y los legítimos intereses económicos» de los consumidores (art. 51); «intereses económicos» de organizaciones profesionales (art. 52); «interés social» (art. 124.1); principio de «solidaridad entre todos los españoles» (art.159.1). Finalmente, también con relación al Estado Social, y a propósito de la forma de Estado (Estado Autonómico), la Constitución española utiliza otro concepto indeterminado, a saber, la «solidaridad» entre las regiones (art. 2).

En lo que respecta a la interpretación de dichas expresiones, el Tribunal Constitucional español ha desarrollado una profusa jurisprudencia respecto de varias de ellas, como la «interdicción de la arbitrariedad»; el «plazo máximo de duración» y «plazo de tiempo razonable»; «honor»; «tutela judicial efectiva»; «intereses legítimos»; «dilaciones indebidas»; «capacidad económica»; «medio ambiente», entre otras ${ }^{41}$.

${ }^{41}$ Una completa revisión sobre estos y otros conceptos indeterminados en la jurisprudencia del Tribunal Constitucional español, puede consultarse en Ortega, D. (2009). Los conceptos jurídicos indeterminados en la jurisprudencia española, Madrid, Dykinson. 
Por su parte, tanto en manuales, tratados o cursos de Derecho Constitucional español, como en artículos u obras monográficas, se ha procurado determinar qué son y cuál es la función de estos conceptos en el Derecho Constitucional ${ }^{42}$, incluido el

42 Estos conceptos son abordados en obras generales de Derecho Constitucional español, como por ejemplo Torres, A. (2004). Principios de Derecho Constitucional español, Madrid, Universidad Complutense de Madrid, 5. ${ }^{\text {ed., }} 2$ vol.; López, L. (2016). Derecho Constitucional, Valencia Tirant lo Blanch, 10. ${ }^{a}$ ed., 2 vol.; Álvarez, E. y Tur, R (2017). Derecho constitucional, Madrid, Tecnos, 7. . ed. Asimismo, y a modo meramente ejemplar, son de consulta obligada algunos trabajos en que analizan específicamente algunos conceptos indeterminados, entre los que se pueden destacar, De la Morena, L. (1986). «La «seguridad pública» como concepto jurídico indeterminado: su concreta aplicación a los traspasos de servicios en materia de espectáculos públicos». Revista de administración pública, N. ${ }^{\circ} 109$, 321 362; García de Enterría, E. (1996). «Una nota sobre el interés general como concepto jurídico indeterminado». Revista Española de Derecho Administrativo, N. 89, 69-89; Salaverría, J.I. (1996) «Principio de Legalidad, conceptos indeterminados y discrecionalidad administrativa». Revista española de derecho administrativo, N. ${ }^{\circ}$ 92, 535-554; Redondo, M.C. (1997). "Teorías del Derecho e indeterminación normativa». Doxa. Cuadernos de Filosofía del Derecho, número 20, CEC-Universidad de Alicante, 177-196; De la Quadra-Salcedo, T. (1998). «La constitución económica de España. Comentario introductorio al título VII», en Oscar, A. (dir.), Comentarios a la Constitución Española de 1978, Tomo X, Madrid, Edersa/Cortes Generales, 15-44; Bocanegra, R.E y Huergo, A.J (2001). «Un paso atrás en el control judicial de la discrecionalidad: su confusión con los conceptos jurídicos indeterminados y la dispensa del deber de motivar». Revista española de derecho administrativo, N. ${ }^{\circ} 111,405-428$; del Real, J.A. (2002). «Sobre la indeterminación del derecho y la ley constitucional: el caso del término «nacionalidades» como concepto jurídico indeterminado». Derechos y libertades: Revista del Instituto Bartolomé de las Casas, Año n. ${ }^{\circ}$ 7, N. ${ }^{\circ}$ 11, 223-249; Cardona, M. (2002). «El valor real como concepto jurídico indeterminado». La comprobación de valores de inmuebles, Madrid, Dijusa, 17-33; González-Trevijano, P. (2003). «Conceptos jurídicos indeterminados y realidades económicas difusas en la Constitución de 1978», en L. Cosculluela Montaner (Coord.), Estudios de Derecho Público Económico: Libro Homenaje al Prof. Dr. D. Sebastián Martín-Retortillo, Madrid, Civitas, 205-218; Prada, J.L. (2003). «Revisión de los principios rectores de la política social y económica y de su actual realidad jurídico-constitucional». Revista de Estudios Políticos (Nueva Época) Núm. 122, 269-316; Ara Pinilla, I. (2004). «Presupuestos y posibilidades de la doctrina de los conceptos jurídicos indeterminados». Anuario de filosofía del derecho, N. ${ }^{\circ}$ 21, 107-124; Fernández, M.Y. (2006). «El concepto jurídico indeterminado de «servicio esencial» en la Constitución española». Revista de administración pública, N. ${ }^{\circ}$ 170, 325-338; Cascajo, J.L. (2008). «En torno a una idea metanormativa de la justicia constitucional». Teoría y Realidad Constitucional, núm. 22, 299-314; González Alomo, A. (2009). «La discrecionalidad y su control. Diferenciación con la arbitrariedad y con los conceptos jurídicos indeterminados». CEFLegal: revista práctica de derecho. Comentarios y casos prácticos, N. o 98, 133 y ss.; Montalvo, J.C. (2010). «Concepto de orden público en las democracias contemporáneas». Revista Jurídica Universidad Autónoma de Madrid, N.22, 197-222; Montalvo J.C. (2011). "Interés público y Administración contemporánea». Universitas: Revista de filosofía, derecho y política, N. ${ }^{\circ} 14,129-149$. Asimismo, uno de los aportes doctrinarios más interesantes a la reflexión sobre los conceptos indeterminados proviene de la doctrina administrativista, y se debe a García de Enterría en su ya célebre trabajo «La lucha contra las inmunidades del poder en el Derecho administrativo (poderes discrecionales, poderes de gobierno, poderes normativos)», apreciaciones reiteradas más tarde en el Curso de Derecho Administrativo escrito con Fernández Rodríguez; García de Enterría, E. (1962). «La lucha contra las inmunidades del poder en el Derecho administrativo (poderes discrecionales, poderes de gobierno, poderes normativos)». Revista de administración pública, N. ${ }^{\circ}$ 38, 159-208; García de Enterría, Eduardo, y Fernández Rodríguez, Tomás Ramón (2013): Curso de Derecho administrativo, vol. I, 16. ${ }^{a}$ ed., Civitas, Madrid. 
significado que el Tribunal Constitucional le ha ido asignando a varios de ellos ${ }^{43}$. Al respecto, es interesante considerar que existen importantes énfasis respecto de la forma en que los poderes públicos deben concretar y especificar el contenido de estos conceptos. Así, y a propósito de la competencia del legislador para desarrollar y dar contenido a conceptos constitucionales indeterminados, Fernández García entiende que, «dentro de lo razonable el legislador puede optar entre varias soluciones constitucionales ${ }^{44}$. En tal sentido, «la actividad interpretativa del legislador que consiste en otorgar un significado a una disposición constitucional no debe ser una actuación arbitraria y, como actividad racional que es, tiene unos límites lógicos, más o menos precisos, que no se pueden extravasar. Lo que resulta evidente es que en la interpretación que el legislador haga del concepto se realizan opciones, esencialmente valorativas, pues toda opción supone una preferencia y toda preferencia, ex definitione, entraña una valoración ${ }^{45}$.

Pero Montalvo destaca acertadamente que indeterminación no es lo mismo que discrecionalidad, porque mientras «lo propio de todo concepto jurídico indeterminado, en cualquier sector del ordenamiento, es que su aplicación permita una sola solución justa, el ejercicio de una potestad discrecional permite una pluralidad de soluciones justas, o lo que es lo mismo, varias alternativas igualmente justas desde la perspectiva del derecho» ${ }^{46}$. En un sentido similar, García de Enterría y Fernández Rodríguez, sostienen que muchas veces se confunde discrecionalidad con conceptos indeterminados, en circunstancias que, a su juicio, en éstos «la discrecionalidad está excluida y que más que remitir la Ley a una decisión libre de la Administración, en cuyo ejercicio saldrían indiferentes jurídicos o contenidos igualmente justos, se trata, por el contrario, de delimitar una única solución justa cuya búsqueda reglada debe hacer la Administración cuando a ella corresponde su aplicación, y cuyo control último, por ser un control de legalidad, es accesible al juez» ${ }^{47}$.

\section{Conceptos indeterminados en la Constitución chilena}

Alineada con el lenguaje constitucional de la segunda mitad del siglo $\mathrm{xx}$, la Constitución chilena exhibe expresamente numerosos conceptos indeterminados a lo

43 Ortega, D. (2009). Los conceptos jurídicos indeterminados en la jurisprudencia española, Madrid, Dykinson. y Ortega, D. (2010). «La especial transcendencia constitucional como concepto jurídico indeterminado: De la reforma de 2007 de la LOTC a la STC 155/2009, de 25 de Junio». Teoría y realidad constitucional, N. ${ }^{\circ} 25,497-513$.

44 Fernández García, M.Y. (2006). «El concepto jurídico indeterminado de «servicio esencial»en la Constitución española». Revista de administración pública, N. ${ }^{\circ} 170,333$.

45 Ibid., 337.

46 Montalvo, J.C. (2011). «Interés público y Administración contemporánea». Universitas: Revista de filosofía, derecho y política, N. ${ }^{\circ} 14,137-138$.

47 García de Enterría, E. y Fernández Rodríguez, T.R. (2013). Curso de Derecho administrativo, vol. I, 16. ${ }^{a}$ ed., Civitas, Madrid, 504. En un sentido similar ver Cassagne, nota 7. 
largo de su articulado. Algunos se vinculan con la persona y con su relación y posición en la comunidad política: «dignidad» (art. 1); «grupos intermedios» (art. 1); «bien común» (art. 1); la «mayor realización espiritual y material posible» (art.1); «seguridad nacional» (art. 1); «naturaleza humana» (art. 5).

Otros dicen relación con los derechos constitucionales, incluidos los sociales, y con su regulación, complementación o limitación por el legislador, cuando la Constitución así lo dispone. Es el caso de expresiones como «vida privada y honra» (art. 19 N. ${ }^{\circ} 4$ ); «moral», «buenas costumbres» y «orden público» (art. 19 N. . 6); la necesidad de la detención o de la prisión preventiva «para las investigaciones o para la seguridad del ofendido o de la sociedad» (art. 19 N. ${ }^{\circ} 7$, letra e); «injustificadamente errónea o arbitraria» (art. $19 \mathrm{~N} .{ }^{\mathrm{a}} 7$, letra i); «medio ambiente libre de contaminación» (art. 19 N. ${ }^{\circ} 8$ ); «promoción, protección y recuperación de la salud», «rehabilitación» (art. 19 N. ${ }^{\circ}$ ); «la moral, las buenas costumbres, el orden público y la seguridad nacional» (art. 19 N. ${ }^{\circ} 1$ ); «moral, al orden público y a la seguridad del Estado» (art. 19 N. ${ }^{\circ} 16$ ); «moral», «seguridad y salubridad públicas», «interés nacional» (art. 19 N. 16 ); «conducta ética» (art, 19 N. ${ }^{\circ} 16$ ); "grave daño a la salud, a la economía del país, al abastecimiento de la población o a la seguridad nacional» (art. 19 N. ${ }^{\circ} 16$ ); «seguridad social» y «prestaciones básicas uniformes» (art. 19 N. $\left.{ }^{\circ} 18\right)$; «la moral, al orden público o a la seguridad nacional» (art. 19 N. ${ }^{\circ} 21$ ); «función social» (art. 19 N. ${ }^{\circ} 24$ ); «intereses generales de la Nación», «seguridad nacional», «utilidad y salubridad públicas», "patrimonio ambiental» (art. 19 N. $\left.{ }^{2} 24\right)$; «utilidad pública», «interés nacional» (art. 19 N. $\left.{ }^{\circ} 24\right)$; «esencia» de los derechos (art. 19 N. ${ }^{\circ} 26$ ); «valores esenciales de la tradición chilena» (art. 22).

Finalmente, existen conceptos que se relacionan con el ejercicio de atribuciones especiales de los poderes públicos: «calamidades públicas», «conmoción interna», «grave daño o peligro para la seguridad nacional» (art. 32 N. ${ }^{\circ} 20$ ); «grave conmoción interior» (art. 40); «calamidad pública» (art. 41); «grave alteración del orden público o de grave daño para la seguridad de la Nación» (art. 42).

A su vez, tanto la doctrina como la jurisprudencia han identificado un concepto no expresamente contenido en la Constitución, pero deducido a partir de sus preceptos, a saber, el denominado «orden público económico». Este ha sido objeto de atención por parte de diversos autores ${ }^{48}$, y recogido y desarrollado por el Tribunal Constitucional $^{49}$.

A lo anterior debe añadirse que, como consecuencia de lo dispuesto en el inciso 2. ${ }^{\circ}$ del art. 5 de la Constitución, los tratados internacionales sobre derechos humanos ratificados por Chile y que estén vigentes, pueden ser también fuente de conceptos indeterminados con impacto constitucional. Y así por ejemplo, la Convención Americana de Derechos Humanos cuenta con diversos preceptos que contienen esa clase

48 Ver notas al pie 62 a 67.

49 Ver por ejemplo sentencias roles 207-1995; 546-2006; 654-2006; 811-2007; 1411-2009; 14142009; 1968-2011; 2133-2011; 2475-2013; 2698-2014. 
de conceptos, a lo que se suma la presencia de un control supranacional, a cargo de la Comisión y de la Corte Interamericana de D.D.H.H. De hecho, la Corte ha desarrollado un concepto que entiende implícito en la Convención, y que además de ser en sí mismo indeterminado, puede obligar a los estados miembro a interpretar los términos abiertos contenidos en la Convención, de acuerdo a la forma en que han sido interpretados por la propia Corte. Se trata del denominado «control de convencionalidad», que tanto la Corte, como parte de la doctrina, entienden que es un concepto implícito en la Convención ${ }^{50}$.

Entre los conceptos indeterminados que contiene la Convención se cuentan, entre otros: «condición social» (art. 1.1); «medidas legislativas o de otro carácter que fueren necesarias» (art. 2); «penas o tratos crueles, inhumanos o degradantes» (art. 5.2); «mayor celeridad posible» (art. 5.5); «readaptación social de los condenados» (art. 5.6); «dignidad» (art. 6.2); «bienestar de la comunidad» (art. 6.3.c); «medios adecuados» (art. 7.2.c); «plazo establecido por la ley» (art. 7.2.e); «detención o encarcelamiento arbitrarios» (art. 7.3); «sin demora» (art. 7.4; 7.6); «deberes alimentarios» (art. 7.7); «plazo razonable» (art. 8.1); «intereses de la justicia» (art. 8.5); «conforme a la ley» (art. 10); «honra», «dignidad» «vida privada» «reputación» (art. 11); «seguridad, el orden, la salud o la moral públicos» (art. 12.3); «propias convicciones» (art. 12.4); «reputación» (art. 13.2.a); «seguridad nacional, el orden público o la salud o la moral públicas» (art. 13.2.b); «abuso de controles oficiales o particulares» (art. 13.3); «protección moral de la infancia y la adolescencia» (art. 13.4); «apología del odio nacional, racial o religioso», «acción ilegal similar» (art. 13.5); «honra y la reputación» (art.14.3); «seguridad nacional», «seguridad pública» «orden público», «salud pública», «moral pública» (art. 15); «restricciones previstas por la ley» (art. 16.2); «seguridad nacional», «de la seguridad o del orden públicos», «salud o moral públicas» (art. 16.2); «medidas apropiadas» (art. 17.4); «interés y convenien-

${ }^{50}$ Sobre el control de convencionalidad como concepto indeterminado e implícito en la Convención Americana de Derechos Humanos, y desarrollado por la Corte Interamericana de Derechos Humanos puede consultarse, entre otros, Albanese, S. (2008). El control de convencionalidad, Buenos Aires, Ediar.; Hitters, J.C. (2009). "Control de constitucionalidad y control de convencionalidad. Comparación». Estudios Constitucionales, año 7, N. . 2, 109-128; Sagüés, N.P. (2010). «Obligaciones internacionales y control de convencionalidad». Estudios Constitucionales, año 8, N. ${ }^{\circ} 1,125$ y ss.; Nogueira, H. (2012b). Derecho constitucional chileno, Santiago, AbeledoPerrot/Thomson Reuters, Tomo I; Nogueira, H. (2014). «Sistema interamericano de protección de derechos humanos, control de convencionalidad y aplicación por parte de las jurisdicciones nacionales». La protección de los derechos bumanos y fundamentales de acuerdo a la Constitución y el Derecho Internacional de los derechos humanos, Santiago, Librotecnia, 395-421; Henríquez, M. (2014). «La polisemia del control de convencionalidad interno». Revista Colombiana de Derecho Internacional N. ${ }^{\circ}$ 24, 113-141; Núñez Donald, C. (2015). Control de Convencionalidad: Teoría y aplicación en Chile, Cuadernos del Tribunal Constitucional, Número 60, Santiago, Tribunal Constitucional de Chile; Silva, M. (2016). «Control de convencionalidad interno y jueces locales: un planteamiento defectuoso». Estudios Constitucionales, Año 14, N. ${ }^{\circ}$ 2, 101-142; Nogueira, H. y Aguilar, C. (2017). Control de convencionalidad, corpus iuris y ius commune interamericano, Santiago, Editorial Triángulo; Henríquez, M. y Morales, A. (2017). El control de convencionalidad: un balance comparado a 10 años de Almonacid Arellano vs. Chile, Santiago, Ediciones Der. 
cia» de los hijos (art. 17.4); «medidas de protección» (art. 19); «arbitrariamente» (art. 20.3); «interés social» (art. 21.1); «indemnización justa» (art. 21.2); «utilidad pública» «interés social» (art. 21.2); «seguridad nacional, la seguridad o el orden públicos, la moral o la salud públicas» (art. 22.3); «interés público» (art. 22.4); «delitos políticos» (art. 22.7); «recurso sencillo y rápido», «recurso efectivo» (art. 25.1); «logro progresivo de la plena efectividad» de los derechos económicos, sociales y culturales; «recursos disponibles» (art. 26); «peligro público», «emergencia que amenace la independencia o seguridad del Estado» (art. 27.1); «bien común» (art. 32.2).

En lo que respecta a la doctrina ius-publicista chilena, la temática de los conceptos indeterminados y supra-jurídicos ha tenido una amplia cobertura. Así, varios trabajos generales de Derecho Constitucional chileno (tratados, manuales, cursos) abordan los diversos conceptos indeterminados presentes en la Constitución, y el rol que a ellos les cabe en dicho ordenamiento ${ }^{51}$. En tal sentido, Cea ve en la Constitución no sólo normas y principios jurídicos, sino que además valores que permiten la actualización de la Constitución. En efecto, en su opinión los valores que están presente en los derechos fundamentales hacen posible una interpretación «más libre», lo que, a su juicio, facilita una mejor armonía entre los derechos y los valores ${ }^{52}$.

A su vez, Nogueira sostiene que los preceptos constitucionales «se van transformando en contacto con el tiempo y los acontecimientos sociales, los cuales van haciendo variar el sentido y alcance de los vocablos empleados en el texto constitucional, como asimismo las concepciones que se desprenden del mismo, el cual debe irse actualizando para mantenerse como un instrumento de gobierno efectivo» ${ }^{53}$. Y por su parte, Ruiz-Tagle entiende que los derechos fundamentales deben vincularse «con la idea de solidaridad y ciudadanía» y con valores como dignidad, igualdad, democracia $^{54}$.

Otro sector de la doctrina se ha referido en específico a algunos conceptos indeterminados, y al papel que le cabe a cada uno en el Derecho Público chileno. A este

51 Entre otros Silva, A. (1997-2006). Tratado de Derecho Constitucional, Santiago, Edit. Jurídica de Chile, 1997-2006, XIII vol.; Cea, J.L. (1988). Tratado de la Constitución de 1980, Santiago, Edit. Jurídica de Chile; Cea, J.L. (2008 y 2012a). Derecho Constitucional chileno, Santiago, Ediciones Pontificia Universidad Católica de Chile, Tomos 1 y 2; Vivanco, A. (2006). Curso de Derecho Constitucional, Santiago, Ediciones Universidad Católica de Chile, Tomo 2; Nogueira, H. (2012b). Derecho constitucional chileno, Santiago, AbeledoPerrot/Thomson Reuters, Tomo I; Verdugo, M., Pfeffer, E. y Nogueira H. (2012). Derecho Constitucional, Santiago, Edit. Jurídica de Chile, 2. ${ }^{a}$ ed.

52 Cea, J.L. (2012). «Algo más sobre la constitucionalización del Derecho», en Renovación del constitucionalismo en Chile, Santiago, AbeledoPerrot/Thomson Reuters, 286.

53 Nogueira, H. (2012b). Derecho constitucional chileno, Santiago, AbeledoPerrot/Thomson Reuters, Tomo I, 412.

54 Ruiz-Tagle, P. (2007). «Una visión democrática y liberal de los derechos fundamentales». En Bordalí Salamanca, Andrés, Justicia Constitucional y derechos fundamentales, Santiago, LexisNexis, 2. a ed., 92, 95 . 
respecto destacan los análisis que hacen Soto Kloss ${ }^{55}$ y Ríos ${ }^{56}$ respecto de la dignidad humana y su rol en el Derecho Constitucional. El propio Soto Kloss ${ }^{57}$ y Silva ${ }^{58}$ se han enfocado también en los grupos intermedios, su significado y consecuencias de su reconocimiento constitucional. También Soto Kloss ${ }^{59}$ y Varela ${ }^{60}$ se han referido a la subsidiariedad, en tanto que $\mathrm{Cea}^{61}, \mathrm{Varela}^{62}$, Fermandois ${ }^{63}$, Ferrada $^{64}$, Navarro ${ }^{65}$ y Avilés $^{66}$, entre otros, han desarrollado en extenso el concepto de orden público económico.

Sin embargo, en la doctrina chilena también se encuentran críticas respecto del uso de dichos conceptos y del lenguaje supra-jurídico ${ }^{67}$, y se destacan los riesgos derivados de su utilización, en particular la interpretación laxa de preceptos ambi-

55 Soto Kloss, E. (1987) «La dignidad de la persona, fundamento de los derechos humanos. Antecedentes veterotestamentarios». Revista de Derecho Público, 41/42, y (2012). Derecho Administrativo. Temas fundamentales, Santiago, AbeldoPerrot/Thomson Reuters, 3. ${ }^{a}$ ed., $49-55$.

56 Ríos, L. (1999). «La dignidad de la persona». Discursos Universitarios, Valparaíso, Universidad de Playa Ancha, 5-35.

57 Soto Kloss, E. (2012). Derecho Administrativo. Temas fundamentales, Santiago, AbeldoPerrot/ Thomson Reuters, 3. . ed, 57-67, 95-106.

58 Silva, A. (1997). Tratado de Derecho Constitucional, Santiago, Edit. Jurídica de Chile T. IV, $42-52$.

59 Soto Kloss, E. (2012). Derecho Administrativo. Temas fundamentales, Santiago, AbeldoPerrot/ Thomson Reuters, 3. ${ }^{\mathrm{a}}$ ed, 119-132 y 133-141.

60 Varela, J. (1989). «Subsidiariedad, orden público económico y seguridad nacional en la Constitución de 1980». Revista Chilena de Derecho 16, 379 y ss. Varela ha desarrollado además el concepto de seguridad nacional.

${ }^{61}$ Cea, J.L. (1988). Tratado de la Constitución de 1980, Santiago, Edit. Jurídica de Chile, 155-180; Derecho Constitucional chileno, Santiago, Ediciones Pontificia Universidad Católica de Chile, (2012), Tomo 2, 503-508.

${ }^{62}$ Varela, J. (1989). «Subsidiariedad, orden público económico y seguridad nacional en la Constitución de 1980». Revista Chilena de Derecho 16, 379 y ss.

63 Fermandois, A. (2000). «El orden público económico bajo la Constitución de 1980». Ius Publicum N. ${ }^{\circ}$ 4, 63-78, y Fermandois, A. (2006). Derecho Constitucional Económico. Garantías Económicas, Doctrina y Jurisprudencia, Santiago, Ediciones Universidad Católica de Chile, Santiago, Tomo I, 2a ed.

${ }^{64}$ Ferrada, J.C. (2000). «La Constitución Económica de 1980: Algunas reflexiones críticas». Revista de Derecho (Valdivia), vol.11, 47-54.

${ }^{65}$ Navarro, E. (2016). La Constitución económica chilena ante los tribunales de justicia, Santiago, Ediciones Universidad Finis Terrae.

66 Avilés, V.M. (2001). «Orden público económico: noción crítica». Revista de Derecho Público (63), 329-338.

${ }^{67}$ Por ejemplo, Martínez, J.I. (2001). «Valor de la incorporación de conceptos meta-jurídicos al lenguaje del derecho constitucional. El caso de la dignidad humana». Revista de Derecho, Pontificia Universidad Católica de Valparaíso XXII, 115-121; Alcalde, E. (2008). «Relación entre valores y principios generales de derecho en la interpretación constitucional de los derechos fundamentales en Chile». Revista Chilena de Derecho, vol. 35 N. ${ }^{\circ}$ 3, 463-484; Covarrubias, I. (2011). «El bien común, el interés público o los fines constitucionalmente legítimos como justificación del regulador para limitar los derechos fundamentales». Litigación Pública, Santiago, Facultad de Derecho, Universidad de los Andes, Legal Publishing, 397-433. Covarrubias, I. (2014b). « ¿Emplea el Tribunal Constitucional el test de proporcionalidad?». Estudios Constitucionales, vol. XII, N. ${ }^{\circ} 1$, 163-237. 
guos, que puede encubrir un poco atractivo activismo judicial ${ }^{68}$, a pesar de los esfuerzos por reducirlo al máximo mediante adecuadas herramientas de control. Así, algunos autores se han ocupado de destacar y desarrollar algunos principios que ayudan a limitar el control judicial a lo propiamente jurídico, y por ende a atenuar o reducir el activismo ${ }^{69}$.

Por su parte, el Tribunal Constitucional ha precisado cuál es el sentido los conceptos indeterminados, al señalar que los términos abiertos «buscan atrapar bajo ciertos estándares o fórmulas verbales, realidades variables» ${ }^{70}$. Asimismo, y haciendo suya la apreciación de García de Enterría y de Fernández ${ }^{71}$, ha sostenido que estos conceptos no son sinónimo de discrecionalidad, pues de ellos sólo resulta válida una única solución justa $^{72}$. Pero además, el Tribunal se ha referido al significado y alcance de diversos conceptos constitucionales indeterminados, como por ejemplo «bien común» ${ }^{73}$, «conteni-

${ }^{68}$ Sobre los riesgos del activismo judical según la doctrina chilena ver, entre otros, Aldunate, E. (2001). «La desconstitucionalización de la Constitución». Revista de Derecho de la Pontificia Universidad Católica de Valparaíso, vol. XXII (2001), 17-38. Aldunate, E. (2011). «Principios jurídicos y neoconstitucionalismo». Carbonell Flavia; Letelier, Raúl, y Coloma, Rodrigo: Principios jurídicos. Análisis y crítica, Santiago, AbeledoPerrot/Thomson Reuters, 143-153; Accatino, D. (2007). «La interpretación de los derechos fundamentales». Bordalí Salamanca, Andrés, Justicia constitucional y derechos fundamentales, Santiago, LexisNexis, 2. ${ }^{a}$. ed., 17-29; Núñez, M. (2010). «El neoconstitucionalismo y el recurso a los valores en la jurisprudencia del Tribunal Constitucional chileno». Revista de Derecho de la Pontificia Universidad Católica de Valparaíso XXXIV, 523-541.

69 En tal sentido destacan los trabajos dedicados a los principios de proporcionalidad, deferencia y margen de apreciación, que operan como mecanismos de atenuación del activismo judicial, y por ende como límites a la libre interpretación de conceptos indeterminados. Al respecto ver Arnold, R., Martínez, J.I. y Zúñiga, F. (2012). «El principio de proporcionalidad en la jurisprudencia del Tribunal Constitucional». Estudios Constitucionales, Año 10, No. 1, 65-116; Martínez, J.I. (2014). «Auto-restricción, deferencia y margen de apreciación. Breve análisis de sus orígenes y de su desarrollo». Estudios Constitucionales, Año 12, N. ${ }^{\circ} 1,365-396$; Covarrubias, I. (2012). «La desproporción del test de proporcionalidad: aspectos problemáticos en su formulación y aplicación. Revista Chilena de Derecho, vol. 39 N. ${ }^{\circ}$ 2, 447-480; Covarrubias, I. (2013) «La renuencia del Derecho Británico a la regla optimizadora en el test de proporcionalidad (y la constatación del mismo resultado en el TC chileno)», en David Ortíz y Katty Aquize (edit.), Constitucionalismo y Principio de Proporcionalidad, Tomo V, (Ara Editores Perú-Colombia), 470501; Covarrubias, I. (2014a). « Emplea el Tribunal Constitucional el test de proporcionalidad?». Estudios Constitucionales, vol. XII, N. ${ }^{\circ}$ 1, 163-237; Covarrubias, I. (2015). «El test de proporcionalidad que se promueve en la tutela de derechos fundamentales con las premisas a las que se adhiere», en Revista de Derecho de la Pontificia Universidad Católica de Valparaíso, vol. XLV, 261 287.

70 Sentencia rol 2541-2013, considerando 59. La posición adoptada por el Tribunal es similar a la propuesta por Arnold y reseñada al comienzo de este trabajo. Ver nota 15.

71 Ver nota 47.

72 Por ejemplo, sentencias roles 1-1971, considerando $19 .^{\circ} ; 1341-2009$, considerandos $14 .^{\circ} \mathrm{y}$ $16 .^{\circ} ; 2684-2014$, considerandos $15^{\circ}$ al $17 .^{\circ} ; 2702-2014$, considerando $16 .^{\circ}$, y 2922-2015, considerando $47 .{ }^{\circ}$.

73 Por ejemplo, sentencias roles 2881-2015, considerandos $9 .^{\circ}$ y $17 .^{\circ}$, y 2693-2014, considerandos 8. ${ }^{\circ}$ al $10 .^{\circ}$ 
do esencial de los derechos $»^{74}$, «derechos fundamentales $»^{75}$, «dignidad $»^{76}$, hhonra» $»^{77}$, «igualdad/discriminación» ${ }^{78}$ y orden público económico ${ }^{79}$.

\section{DIFICULTADES QUE CONLLEVA EL USO DE CONCEPTOS INDETERMINADOS EN EL DERECHO CONSTITUCIONAL}

La somera revisión efectuada precedentemente, demuestra que en el Derecho existen ciertos grados de indeterminación. Como se dijo antes, esto se debe no sólo al uso deliberado de este tipo de expresiones, sino también a que, como destacaba Hart, en el Derecho hay algunos ámbitos que presentan una «textura abierta», que es propia del lenguaje humano ${ }^{80}$. Aquello supone asumir que en el Derecho existe lo que MacCormick llama «un grado aceptable» de indeterminación ${ }^{81}$, que se relaciona con el carácter dialéctico y argumentativo del Derecho. En otros términos, «la indeterminación jurídica no es simplemente (aunque también) un resultado del hecho de que los Estados comuniquen sus materiales jurídicos en lenguas naturales («oficiales»), y de que estas estén afectadas por la ambigüedad, la vaguedad y la textura abierta. También es un resultado de, y en cierta medida se ve aumentada por, el debido reconocimiento de los «derechos de la defensa» en el contexto de cualquier proceso penal o litigio civil ${ }^{82}$.

No obstante, se debe ser consciente de que, como señala el propio MacCormick, el Estado de Derecho implica el sometimiento del poder al Derecho. Esto supone $\ll[T]$ ener unas leyes adecuadamente publicadas y futuras, la igualdad de

${ }^{74}$ Por ejemplo, sentencias roles 43-1987, considerandos $21 .^{\circ}$ y $22 . .^{\circ} ; 200-1994$, considerando $4 .^{\circ}$; 792-2007, considerando $25 .^{\circ}$.

75 Por ejemplo, sentencia rol 1710-2010, considerando 89..

76 Por ejemplo, sentencias roles 389-2003, considerando $17 .{ }^{\circ} ; 433-2005$, considerando $24 .^{\circ}$ y $25 .^{\circ}$; 521-2006, considerando 18..$^{\circ}$; 976-2007, considerando 22..$^{\circ} ; 1287-2008$, considerando $17 .^{\circ} ; 1273-2008$, considerandos $23 .^{\circ}$ y $24 .^{\circ} ; 1684-2010$, considerandos $28 .^{\circ} 31 .^{\circ} ; 1710-2010$, considerandos $85 .^{\circ}$ al $87 .^{\circ}$; 2915-2015, considerandos $4 .^{\circ}$ y $15 .^{\circ}$.

77 Por ejemplo, sentencias roles 1361-2009, considerando $7 .{ }^{\circ} ; 1419-2009$, considerando $8 .^{\circ}$; 1463 2009, considerando 17. ${ }^{\circ} ; 2454-2013$, 2747-2014, 2801-2015, 2860-2015, 2887-2015, considerandos $15 .^{\circ}$ y $21 .^{\circ} ; 2915-2015$, considerandos $4 .^{\circ}$ y $15 .^{\circ}$.

78 Por ejemplo, sentencia roles $53-1988$, considerandos $12 .^{\circ}$ y $13 .^{\circ} ; 203-1994$, considerando $11 .^{\circ}$; 1273-2008, considerando 52. ${ }^{\circ} ; 1684-2010$, considerandos $38 .^{\circ}$ y 39. $.^{\circ}, 2935-2015$, considerandos $27 . .^{\circ}$ al $35 . \circ$.

79 Ver nota al pie 49. La revisión y análisis del tratamiento de estos conceptos indeterminados por parte del Tribunal Constitucional chileno, es parte de un trabajo que está en preparación.

${ }^{80}$ Hart, H.L.A. (2004). El concepto de Derecho, Buenos Aires, Abeledo-Perrot, reimpresión 2. ${ }^{a}$ ed., 159-169.

81 MacCormick sostiene en todo caso que «la certeza es inalcanzable», por lo que sólo puede aspirarse a disminuirla para hacerla aceptable; MacCormick, N. (2016). Retórica y Estado de Derecho. Una teoría del razonamiento jurídico, Lima, Palestra, 46.

82 Ibid., 69-70. 
los ciudadanos ante ellas, y una limitación del poder oficial respecto a ellas» ${ }^{83}$, lo que «no sería posible si las leyes y los argumentos sobre ellas dieran solo una apariencia de inteligibilidad», porque de ser así, «cuando llegara el momento de aplicarlas, cualquier cosa valdría, debido a la indeterminación radical de los textos jurídicos y la ausencia de cualquier fundamento razonable para preferir una interpretación a otra» ${ }^{84}$. En un sentido similar se pronuncia Yowell, quien destaca también la relevancia que tiene la claridad conceptual como un elemento clave y estratégico para el Estado de Derecho, lo que supone una especial exigencia para las normas jurídicas de carácter general, como la ley ${ }^{85}$.

En otros términos, si bien existen grados razonables de indeterminación en el Derecho, los poderes públicos tienen el deber de dictar normas dotadas de claridad, que sean lo más fácilmente comprensibles, porque, como señala Ara Pinilla, a menor «indeterminación del lenguaje normativo, menos serán los problemas para alcanzar la solución adecuada e indiscutible al caso que se presenta ante el juez» ${ }^{86}$.

Aunque aquello es una obligación de especial relevancia en la labor del legislador, no cabe duda que su importancia también se extiende al Derecho Constitucional, en donde un uso profuso o desmedido de conceptos constitucionales ambiguos o indeterminados puede suponer especiales riesgos y complejidades, atendido el carácter tan jurídico como político de la Constitución ${ }^{87}$. Y así por ejemplo, desde el punto de vista jurídico la indeterminación puede afectar a la confianza legítima y a las legítimas expectativas, y con ello a la previsibilidad, es decir, a lo que las personas pueden razonablemente esperar de la actuación de los poderes públicos, sobre todo en materias clave como la regulación de los derechos y libertades, en donde la mayor o menor precisión de los conceptos pareciera ser una cuestión especialmente álgida.

Todo esto puede tornarse aún más complejo cuando una Constitución incorpora el lenguaje del constitucionalismo social, esto es, del Estado Social y de los derechos sociales (particularmente los que consisten en prestaciones), ya que aquello conlleva necesariamente la inclusión de conceptos indeterminados. Esto se debe a que, como señala Loewenstein, la misma expresión «Estado Social» resulta ambigua, «dado su

83 Ibid., 32-33.

84 Ibid., 33.

${ }^{85}$ El trabajo de Yowell está dedicado precisamente al análisis de la claridad normativa como requisito esencial del Estado de Derecho. Yowell, P. (2012). «Legislación, common law, y la virtud de la claridad». Revista Chilena de Derecho, vol. 39, N. ${ }^{\circ} 2$.

${ }^{86}$ Ara Pinilla, I. (2004). «Presupuestos y posibilidades de la doctrina de los conceptos jurídicos indeterminados». Anuario de filosofía del derecho, N. ${ }^{\circ} 21,108$.

${ }^{87}$ Sobre la doble naturaleza de la Constitución ver por ejemplo García de Enterría, E. (1983). La Constitución como norma y el Tribunal Constitucional, Madrid, Civitas; Vigo, R.L. (1994). Interpretación constitucional, Buenos Aires, AbeledoPerrot, 53-62; Pereira, A.C. (2016). Lecciones de Teoría Constitucional y otros escritos, Santiago de Compostela, Andavira, 51-56. 
carácter de concepto jurídico indeterminado ${ }^{88}$. A esto se agrega el hecho de que, en los derechos sociales consistentes en prestaciones, su contenido constitucional es de gran imprecisión, por lo que su especificación y consecuente operatividad dependerá esencialmente del legislador ${ }^{89}$.

En cualquier caso, lo cierto es que un sistema constitucional y democrático supone asumir que las constituciones no pueden regular todo su contenido de manera exhaustiva. Éstas deben centrarse más bien en las bases, principios y estructuras esenciales, de manera que su desarrollo y regulación lo lleve a cabo el legislador, y su aplicación y adaptación los jueces ${ }^{90}$. En palabras de Cascajo, esto implica reconocer que las constituciones tienen siempre un cierto grado de ductilidad ${ }^{91}$, y por ende algunos ámbitos de indeterminación. Por eso, con el fin de no afectar más allá de lo razonable el objetivo propio de toda Constitución, que no es más que la limitación del poder ${ }^{92}$, se debe ser especialmente cuidadoso en el uso del lenguaje, y no sucumbir a la tentación del uso prolífico de conceptos abiertos, al menos por tres razones.

La primera, se relaciona con el hecho de que, como acertadamente apuntan García de Enterría y Fernández Rodríguez, existe una relación entre conceptos indeterminados y discrecionalidad, y a veces se ha entendido que esto conllevaría una total libertad del órgano encargado de interpretar y aplicar el respectivo concepto ${ }^{93}$. Pero

${ }^{88}$ Loewenstein, K. (1986). Teoría de la Constitución, Barcelona, Ariel, 165. A propósito de la Constitución alemana, Forsthoff opina que la expresión «Estado social» utilizada por la Constitución alemana tendría originalmente un carácter indeterminado, y por ende carecería de un contenido específico. A su juicio, de este concepto no podían «deducirse derechos ni deberes concretos, ni instituciones»; Forsthoff, E. (1986). «Problemas constitucionales del Estado Social», en Abendroth, Wolfgang; Forsthoff, Ernst, y Doehring, Karl: El estado social, Madrid, Centro de Estudios Constitucionales, 45 y ss., 97. Ratificando lo anterior, Arnold señala que esta cláusula es un principio que debe ser concretado por el legislador; Arnold, R. (1993). «Bases dogmáticas del principio del estado social en el derecho constitucional alemán». v.v.a.a. Estudios sobre el estado social. El estado social y la Comunidad Autónoma de Andalucía, Madrid, Parlamento de Andalucía-Tecnos, 34.

89 Sobre los límites de los derechos sociales consistentes en prestaciones ver Martínez, J.I. (1997). Jurisprudencia constitucional española sobre derechos sociales, Barcelona, Cedecs, y (2010). «Los derechos sociales de prestación en la jurisprudencia chilena». Estudios Constitucionales, Año 8, No. 2, 125-166.

${ }^{90}$ Aragón Reyes señala a este respecto que «los enunciados constitucionales, incluidos los declaratorios de derechos, son, por necesidad, tan generales y sintéticos que requieren, en su aplicación a los casos, de modulaciones y especificaciones, o lo que es igual, de concreciones interpretativas de indudable magnitud»; Aragón Reyes, Manuel (2013): Estudios de Derecho Constitucional, Madrid, Centro de Estudios Políticos y Constitucionales, $3{ }^{a}$ Ed., 548.

${ }^{91}$ Cascajo, J.L. (2008). «En torno a una idea metanormativa de la justicia constitucional». Teoría y Realidad Constitucional, núm. 22, 303.

${ }_{92}$ Evidentemente el fin de una Constitución dependerá del concepto que de ella se tenga. En este trabajo se asume que es un límite al poder por medio del Derecho, con el objeto de garantizar la dignidad y derechos esenciales del ser humano. Las diversas acepciones de Constitución pueden consultarse en Pereira, A.C. (2016). Lecciones de Teoría Constitucional y otros escritos, Santiago de Compostela, Andavira, 19-22.

${ }^{93}$ García de Enterría, E. y Fernández, T.R. (2013). Curso de Derecho administrativo, vol. I, 16. ${ }^{a}$ ed., Civitas, Madrid, 504. En concreto estos autores señalan que «una buena parte de los supuestos tradicionalmente tenidos por atribuciones de potestad discrecional por las Leyes no son sino el enunciado de simples conceptos jurídicos indeterminados. Durante mucho tiempo, especialmente tras la formulación 
como señalan estos mismos autores, aquello no sólo no es inadmisible, sino que, como sostiene Montalvo, constituiría una «impune injerencia de los poderes públicos en la regulación de un amplio elenco de derechos y libertades públicas» ${ }^{94}$. Todo eso con el riesgo de que, so pretexto de su determinación, el concepto de que se trate se use para imponer valores, percepciones y visiones particulares por parte de quien detenta dicho poder, transformando dicha «interpretación» en una forma espuria de ética oficial.

La segunda razón, radica en que el desarrollo y concreción de los conceptos indeterminados supone siempre un desafío al delicado equilibrio que implica la separación de poderes, lo que en palabras de la Constitución de Chile, conlleva que los órganos del Estado deben actuar «dentro de su competencia» (art. 7). Pero como por regla general aquellos conceptos deben ser precisados por parte del legislador y del ejecutivo, existe el riesgo de que se generen conflictos interpretativos entre ambos, o entre éstos y los jueces, quienes en un sistema constitucional son los llamados a controlar la actuación de los órganos de poder político.

Dicho riesgo puede acrecentarse si se considera además que los sistemas supranacionales de derechos humanos, como el europeo y el interamericano, cuentan con mecanismos jurisdiccionales de protección de esos derechos. En su labor de tutela de éstos, la Corte Europea de Derechos Humanos y la Corte Interamericana de Derechos Humanos interpretan los preceptos que los contienen, muchos de los cuales albergan también conceptos indeterminados. Esto puede conducir a una colisión entre la interpretación que hagan dichos órganos y la que hacen los estados, lo que puede traer una consecuencia no deseada, a saber, que se ponga en cuestión el control judicial cuando los jueces (incluidos los supranacionales) entran a «valorar una decisión político-social y político económica de los detentadores del poder — gobierno y parlamento— ${ }^{95}$. Es lo que puede ocurrir cuando el juez controla la constitucionalidad de una norma infra constitucional, que ha desarrollado y dotado de contenido a un concepto indeterminado. $\mathrm{Y}$ es que si bien el control judicial está sujeto a ciertos límites, como los impuestos por ejemplo por los principios de razonabilidad y de proporcionalidad, no debe perderse de vista que este último implica aplicar el denominado «test de proporcionalidad». Este conlleva el enjuiciamiento de la idoneidad de la norma, así como su proporcionalidad en sentido estricto ${ }^{96}$, lo que necesariamente llevará al juez a

clásica del concepto de discrecionalidad por el austríaco Tezner, se identificó ésta con la utilización por la Ley de conceptos imprecisos, entendiéndose que en tales casos habría que interpretar que la precisión última de dichos conceptos correspondía discrecionalmente a la Administración»; Ibid.

${ }^{94}$ Montalvo, J.C. (2010). «Concepto de orden público en las democracias contemporáneas. Revista Jurídica Universidad Autónoma de Madrid, N. ${ }^{\circ} 22,203$.

${ }^{95}$ Loewenstein, K. (1986). Teoría de la Constitución, Barcelona, Ariel, 312.

${ }^{96}$ Sobre el principio de proporcionalidad y su aplicación en el control judicial ver Arnold, R. Martínez, J.I. y Zúñiga, F. (2012). «El principio de proporcionalidad en la jurisprudencia del Tribunal Constitucional». Estudios Constitucionales, Año 10, No. 1, 65-116; Covarrubias, I. (2012). «La desproporción del test de proporcionalidad: aspectos problemáticos en su formulación y aplicación». Revista Chilena de Derecho, vol. 39 N. ${ }^{\circ}$ 2. y (2014a). « ¿Emplea el Tribunal Constitucional el test de proporcionalidad?». Estudios Constitucionales, vol. XII, N. ${ }^{\circ}$ 1, 447-480. 
pronunciarse sobre el significado y contenido del concepto indeterminado, con los riesgos que esto supone si no actúa con deferencia y con respeto al legítimo margen de apreciación de los órganos de poder político ${ }^{97}$.

Esta dificultad puede agravarse producto de la penetración de la teoría elaborada por la jurisprudencia alemana, que concibe a los derechos como un orden objetivo de valores positivizados en la Constitución, doctrina que tiene su origen en la sentencia Lüth del Tribunal Constitucional Federal alemán. A partir de ella se ha extendido en la jurisprudencia y en la doctrina alemana y de otros sistemas constitucionales, la idea de que los conceptos jurídicos indeterminados deben precisarse y llenarse de contenido por el legislador con respecto al conjunto del ordenamiento constitucional, en cuanto éste conforma un orden coherente de valores ${ }^{98}$. Consecuencia de lo anterior es que los derechos fundamentales se transforman en un criterio para la «fijación del alcance preciso de cualquier norma del ordenamiento» ${ }^{99}$.

Como se puede apreciar, la combinación entre conceptos jurídicos indeterminados y la idea de derechos como valores, puede resultar francamente riesgosa. Ello no sólo porque el lenguaje de los valores parece ser más filosófico-moral que jurídico ${ }^{100}$, sino

97 En el peor de los casos, el activismo judicial puede conducir a dos situaciones poco deseables, descritas por Aragón, a saber, poner en riesgo el pluralismo político y el principio democrático «en cuanto que sería un poder del Estado no estrictamente representativo el encargado de concretar el "estatus civitatis" ", y debilitar los principios de generalidad del Derecho y de igualdad; Aragón. M. (2013). Estudios de Derecho Constitucional, Madrid, Centro de Estudios Políticos y Constitucionales, 548. Sobre deferencia y margen de apreciación en el control judicial ver Martínez, J.I. (2014). «Auto-restricción, deferencia y margen de apreciación. Breve análisis de sus orígenes y de su desarrollo». Estudios Constitucionales, Año 12, N. ${ }^{\circ} 1,365-396$. Martínez, J.I. (2015). «La deferencia del Tribunal Constitucional respecto del juez de la gestión pendiente en la cuestión de inaplicabilidad». Estudios Constitucionales, Año 13, N. ${ }^{\circ} 1,237-270$.

98 La influencia de la «doctrina Lüth» se hizo notar en España ya en 1981, cuando el Tribunal Constitucional declaraba que «los derechos fundamentales y de las libertades públicas, ...constituyen el fundamento mismo del orden político-jurídico del Estado en su conjunto», y que aquellos derechos tienen un doble carácter, ya que en primer lugar «son derechos subjetivos, derechos de los individuos no sólo en cuanto derechos de los ciudadanos en sentido estricto, sino en cuanto garantizan un status jurídico o la libertad en un ámbito de la existencia. Pero al propio tiempo, son elementos esenciales de un ordenamiento objetivo de la comunidad nacional, en cuanto ésta se configura como marco de una convivencia humana justa y pacífica, plasmada históricamente en el Estado de Derecho y, más tarde, en el Estado social de Derecho o el Estado social y democrático de Derecho, según la fórmula de nuestra Constitución (art. 1.1)» (sentencia 25/1981, fundamento jurídico 5). Por su parte, en Chile, el Tribunal Constitucional, en sus sentencias roles 2626 y 2627, ha citado expresamente el caso Lüth para fundamentar el efecto objetivo y subjetivo de los derechos, y en concreto, el efecto horizontal de éstos (ambas en los considerados 22 y 23).

99 Bayón, J.C. (2000). «Derrotabilidad, indeterminación del derecho y positivismo jurídico». Isonomía N.' $13,88$.

100 Sobre el peligro de entender los derechos como valores positivizados ver, entre otros, Aldunate, E. (2011). «Principios jurídicos y neoconstitucionalismo», en Carbonell, F,; Letelier, R.; y Coloma, R., Principios jurídicos. Análisis y crítica, Santiago, AbeledoPerrot/Thomson Reuters, 143-153; Pereira, A.C. (2016). Lecciones de Teoría Constitucional y otros escritos, Santiago de Compostela, Andavira, 91-106; Núñez Poblete, M. (2010), «El neoconstitucionalismo y el recurso a los valores en la jurisprudencia del Tribu- 
porque además se abre una vía que puede llevar a que el intérprete se vea tentado a interpretar conforme a la manera en que él entiende dichos valores, transformando la Constitución, la Ley o la sentencia, según el caso, en textos más próximos a la ética que al Derecho ${ }^{101}$.

Finalmente, una tercera razón que torna peligroso el uso de conceptos indeterminados en el lenguaje constitucional se relaciona con la discrecionalidad, ya que esos términos requieren ser precisados mediante normas o por la interpretación judicial. En ambas opciones puede presentarse un problema similar, a saber, que se quiera dar a la expresión utilizada el sentido o significado más acorde a las inclinaciones o visiones personales de quienes ejercen las funciones normativas o judiciales. Si bien la concreción normativa del concepto puede controlarse judicialmente (la discrecionalidad supone razonabilidad, y por ende no es sinónimo de falta de $\operatorname{control}^{102}$ ), no puede desconocerse que aquello puede llevar a la paradoja de que la decisión judicial imponga una interpretación, y por ende eventualmente una visión valórica, sin posibilidad de control.

Por todo eso, puede concluirse con Montalvo que «todo concepto jurídico indeterminado genera incertidumbre en un sistema democrático que pretenda establecer fórmulas reales para la resolución objetiva de conflictos» ${ }^{103}$. Y la razón es simple: si bien la discrecionalidad de los poderes políticos es inadmisible en un auténtico sistema constitucional, también lo es la discrecionalidad judicial. En efecto, lo propio del

nal Constitucional chileno». Revista de Derecho de la Pontificia Universidad Católica de Valparaíso XXXIV, 534-535; Núñez Leiva, J.I. (2013). Neoconstitucionalismo y control de constitucionalidad de la ley. ¿El constitucionalismo del Derecho libre?, México, Porrúa, 78-104.

${ }^{101}$ El denominado «neoconstitucionalismo» postula que la Constitución es un instrumento fuertemente axiológico, cuyos valores permiten afrontar la resolución de problemas políticos, económicos y morales. En esta doctrina los jueces juegan un rol trascendental, porque tienen el deber de aplicar dichos valores. Así, y como indica Núñez Leiva, uno de los supuestos del neoconstitucionalismo es que «la Constitución no es sólo una regla del juego sino parte del mismo a través de la inclusión de numerosas cláusulas materiales o de principio, en suma cláusulas materiales o con denso contenido axiológico que pretenden incidir en la agenda política en áreas tan diversas como el modelo económico o la acción del estado en las esferas de la educación o sanidad». Más aún, «el sustrato del Neoconstitucionalismo, podría resumirse así: la existencia de sistemas normativos encabezados por una Constitución - _...- que pretende condicionar de modo importante las decisiones de las mayorías a través de su carga axiológica y de las instituciones jurisdiccionales que garantizan su supremacía y en donde, a consecuencia de lo anterior, el protagonismo en la concreción de las disposiciones constitucionales no corresponde al legislador sino a los jueces». Núñez Leiva, J.I. (2013). Neoconstitucionalismo y control de constitucionalidad de la ley. ¿El constitucionalismo del Derecho libre?, México, Porrúa, 80-81.

102 Como señala Montalvo « $[\mathrm{L}] \mathrm{a}$ actividad discrecional no ha de ser caprichosa, ni arbitraria, ni ser utilizada para producir una desviación de poder sino, antes al contrario, ha de fundarse en una situación fáctica probada, valorada a través de previos informes que la norma jurídica de aplicación determine e interpretados y valorados dentro de la racionalidad del fin que aquélla persigue. Es decir, se presume una racionalidad inherente a su ejercicio de la potestad discrecional, cuya meta debería entenderse como la consecución del interés general». Montalvo, J.C. (2011). «Interés público y Administración contemporánea». Universitas: Revista de filosofía, derecho y política, N. ${ }^{\circ} 14,138$.

103 Ibid., 137. 
constitucionalismo es el sometimiento de todos al Derecho, lo que evidentemente incluye también a los jueces. En tal sentido, los conceptos indeterminados representan para ellos un especial desafío de deferencia y de respeto al margen de apreciación del poder político, y exigen un necesario esfuerzo por no involucrarse en temáticas que escapan no sólo a su competencia, sino que también a la de los demás poderes. Es decir, los jueces no deben transformarse en agentes políticos, económicos, éticos, ni en pseudocientíficos, que a través de sentencias pretendan resolver no sólo problemas jurídicos, sino que también los de naturaleza moral, política, económica, y hasta científica $^{104}$.

Para disminuir los riesgos de la indeterminación en el lenguaje constitucional, parece sensato seguir el consejo de Wheare. El profesor de Oxford recomendaba asumir que las constituciones no pueden pretender agotar la regulación exhaustiva de las instituciones que ellas contemplan, cuestión que debe entregarse más bien al legislador $^{105}$. A su vez, sugería que los textos constitucionales fuesen breves, y sus preceptos lo más jurídicos posible ${ }^{106}$, lo que a mi juicio puede lograrse con más facilidad si las constituciones se encargan fundamentalmente de limitar el poder.

\section{UN NUEVO PROBLEMA: DE CONCEPTOS DETERMINADOS A CONCEPTOS CONTROVERTIDOS}

Como se señaló, el lenguaje constitucional no está exento de los problemas propios del que se usa en otras normas, como la ley. Así, los preceptos constitucionales pueden tener también algún grado de indeterminación, ya que su formulación involucra una cierta abstracción. A esto se agrega el hecho de que a veces puede resultar conveniente el uso de algunos conceptos indeterminados, porque permite que la Constitución se centre en lo esencial, según su fin ${ }^{107}$. Esto se traducirá esencialmente en el reconocimiento y garantía de derechos y libertades, y la fijación de límites y competencias a los poderes públicos, y que entregue su desarrollo al legislador, y su aplicación al juez.

Por ende, y más allá de los problemas que acarrea siempre el lenguaje en el ámbito del Derecho, cuando el constituyente utiliza intencionadamente conceptos indeterminados, lo hace con el objetivo de que la norma que los contiene sea precisada o especificada por quien debe desarrollarla o aplicarla (el legislador y, en su caso, por el

104 Precisamente la pretensión de hacerse cargo de la resolución de temáticas supra-jurídicas, puede llevar a que el juez pase por alto por ejemplo principios de la ciencia económica (v.gr., la escasez de los recursos) o de las ciencias biológicas, como la embriología (v.gr., para desconocer o poner en duda que el comienzo biológico de la vida se da a partir de la unión de los gametos), todo ello con el fin de aplicar y satisfacer los «valores constitucionales», tal y como son entendidos por él.

105 Wheare, K.C. (1975). Las constituciones modernas, Barcelona, Labor, 9.

106 Ibid., 54.

107 Ver nota 92. 
juez). En tal sentido, es usual que en materia de reconocimiento de derechos el constituyente utilice conceptos indeterminados con la idea de fijar estándares o límites, que ayuden a determinar el contenido y significado de cada uno de aquéllos.

Sin embargo, parece evidente que el margen entregado por la Constitución al legislador, no significa que cualquier tipo de concreción o especificación sea válido. Por el contrario, la indeterminación no supone ni puede suponer una especie de cheque en blanco para que los poderes públicos le den el contenido que libremente estimen $^{108}$. Ello no es posible en una comunidad política que cuente con un efectivo y real Imperio del Derecho, lo que entre otras cosas implica el sometimiento de aquellos poderes al Derecho, y el control judicial de éstos.

El problema es que no todos los conceptos indeterminados son fáciles de traducir a estándares jurídicos. De hecho, es probable que un juez se sienta más cómodo y le sea más fácil aplicar normas que incorporen conceptos como «buena fe» $\mathrm{o}$ «diligencia de un buen padre de familia», que aquéllas en que esos estándares se fijan mediante expresiones como «función social»o «interés nacional». Esto se debe a que el uso de estos últimos requiere de valoraciones que van más allá de lo jurídico, pues su naturaleza es más bien política o económica, ámbitos que corresponden a la competencia del legislador y del ejecutivo, y no del juez.

No obstante, esa misma incomodidad del juez frente a ciertos conceptos normativos, puede alcanzar también a los órganos del poder político, cuando se trata de normas que contienen estándares supra-políticos, o supra-económicos, que han sido incorporados con el fin de, o bien limitar, o bien habilitar la actuación de dichos órganos. Este sería el caso por ejemplo de conceptos como «dignidad humana»o «bien común». Se trata de formulaciones que aparentan decirnos mucho más de lo que en verdad nos dicen, y respecto de los cuales en principio pareciera haber un mayor consenso sobre su significado del que realmente tienen. Se trata de las expresiones que W.B. Gallie ${ }^{109}$ denominó «conceptos esencialmente controvertidos» («essentially contested concepts»), es decir, conceptos respecto de los cuales se puede identificar un aspecto medular común, pero que inevitablemente dan lugar a definiciones que compiten entre sín $^{110}$.

Al respecto, debe considerarse que una de las características paradojales de la posmodernidad, es la transformación de conceptos que eran considerados claros, en «conceptos indeterminados y controvertidos». Probablemente esto es consecuencia de

${ }^{108}$ García Salgado explica esto de la siguiente manera: «cuando el legislador utiliza conceptos indeterminados está invitando a los operadores jurídicos a que sean ellos quienes los precisen y está renunciando a petrificar un único sentido concreto y con ello una única solución concreta, sin que esto quiera decir que sea válido cualquier resultado». García, M.J. (2003). «Determinar lo indeterminado: sobre cláusulas generales y los problemas que plantean». Anuario de Filosofía del Derecho N. ${ }^{\circ} 20,111$.

109 El nombre del trabajo de Gallie es precisamente «Essentially Contested Concepts»; Gallie, W.B. (1956). «Essentially Contested Concepts», Proceedings of the Aristotelian Society, Vol.56, 167-198.

110 Valentini, L. (2011). Justice in a Globalized World: A Normative Framework, Oxford, Oxford University Press, 126. 
aquella corriente de pensamiento denominada «constructivismo», según la cual «habiendo creado el hombre las instituciones de la sociedad y de la civilización, debe ser también el mismo hombre capaz de alterarlas a su voluntad para satisfacer sus anhelos o deseos» ${ }^{111}$. Entre los diversos problemas que conllevan las posiciones constructivistas $^{112}$ se encuentran los relativos al uso del lenguaje, lo que en el ámbito jurídico supone asumir que por regla general los conceptos utilizados por el Derecho han sido introducidos en él deliberada y voluntariamente ${ }^{113}$. Esta visión es consistente con lo que señala Bayón, quien, fundado en una premisa propia del positivismo jurídico (y por ende del constructivismo), sostiene que el «derecho es una realidad convencional», y por ende «las convenciones que lo constituyen» no tienen «cierto contenido particular» ${ }^{114}$.

El problema es complejo, sobre todo si se considera que, como señala Ara Pinilla, la utilización de conceptos indeterminados parece ser inevitable en el lenguaje del Derecho, porque éste «funciona de hecho sobre la base del significado que sus diversos destinatarios atribuyen a sus enunciados y no sobre la base del significado que a cada uno de ellos le quiere dar en los distintos supuestos el emisor del lenguaje jurídico (el legislador en sentido amplio), porque el destinatario del derecho obedece o desobedece a la norma en la configuración que él mismo le atribuye, no en la configuración que el legislador pretende ingenuamente que le atribuya. Podría en este sentido decirse que la perspectiva que ofrece el emisor del lenguaje jurídico nos permite conocer a lo sumo cuál es la voluntad que subyace al dictado de los enunciados jurídicos, esto es, cuál es el modo en que el legislador desea que funcione el derecho, pero en ningún caso cuál es el modo en que realmente funciona éste» ${ }^{115}$.

Por lo anterior, el uso de conceptos indeterminados debe llevarse a cabo asumiendo que implica un muy frágil equilibrio entre aquéllos y la seguridad jurídica ${ }^{116}$. Y

${ }^{111}$ Hayek, F.A. (1988). «Los errores del constructivismo». Estudios Públicos N. ${ }^{\circ} 29,86$.

${ }_{112}$ Una interesante crítica al constructivismo puede verse en Hayek, op. cit.

${ }^{113}$ Hayek destaca que las reglas de conducta que hacen posible la formación del orden social son de tres clases: 1 . Las que «se observan de hecho, pero que nunca han sido afirmadas de palabra», y que se aplican aún sin conocerlas explícitamente; 2. Las que si bien están traducidas a palabras, expresan simplemente «lo que desde hace tiempo ha sido observado en la acción», y 3 . Las «que han sido introducidas deliberadamente y, por lo tanto, existen necesariamente como palabras dispuestas en frases»; ibíd. 92.

${ }^{114}$ Bayón, J.C. (2000). «Derrotabilidad, indeterminación del derecho y positivismo jurídico». Isonomía N. ${ }^{\circ} 13,116$. Para Bayón el Derecho entero podría estar configurado en su totalidad por «normas derrotables», 117. En sentido contrario se pronuncia Segura, para quien «no sería admisible la atribución de cualquier significado al contenido de las normas»; Segura, 675. Al respecto, y desde un punto de vista no positivista, si se extremase lo planteado por Bayón, podría llegarse a desproveer al Derecho de ciertos componentes que son los que hacen que éste sea tal, como la razonabilidad, la previsibilidad y la seguridad jurídica, y, en el peor de los casos, la idea misma de justicia.

115 Ara Pinilla, I. (2004). «Presupuestos y posibilidades de la doctrina de los conceptos jurídicos indeterminados». Anuario de filosofía del derecho, N. ${ }^{\circ} 21,109$.

${ }^{116} \mathrm{Al}$ respecto Ara Pinilla señala que «[C]uanto menor sea la indeterminación del lenguaje normativo, menos serán los problemas para alcanzar la solución adecuada e indiscutible al caso que se presenta ante el juez»; ibíd., 108. 
si esto es en sí mismo un problema, parece que puede acrecentarse aún más si se entiende que los conceptos jurídicos son esencialmente un producto de la voluntad, pues puede conducir a transformar lo que es claro y preciso, en algo indeterminado o controvertido. En otros términos, el lenguaje utilizado por una norma podría carecer de relevancia, debido a que el intérprete puede poner en duda el significado de un concepto que tiene un sentido claro, o que simplemente le dé otro. Al respecto, García Salgado sostiene que lo habitual es que «presuponemos que cuando los conceptos son determinados, y muchas veces ocurre, el juez se limita a aplicarlos sin buscarles los dobleces que no tienen; y sin embargo un análisis de sentencias nos muestra la cantidad de ocasiones en las que el juez encuentra mecanismos interpretativos para dejar de aplicar las normas aparentemente claras, dibujándonos un legislador en “constante pie de guerra con su lengua materna" ${ }^{117}$. Como se comprenderá, todo aquello puede llevar incluso a prescindir de la exigencia de razonabilidad del Derecho, afectándose así las legítimas expectativas y la seguridad jurídica ${ }^{118}$.

En tal sentido, puede ser interesante considerar la situación del concepto de matrimonio, que durante siglos ha sido entendido como la unión contractual entre un hombre y una mujer. Sin embargo, en los últimos años se observa en algunos países occidentales una tendencia a reformular el concepto, lo que ha llevado a sus órganos legislativos y judiciales a reinterpretarlo. Así ocurrió por ejemplo con la ley de las Cortes Generales de España 13/2005, y la sentencia del Tribunal Constitucional español 198/2012, de 6 de noviembre, que resolvió un recurso de inconstitucionalidad en contra de la referida ley. La norma impugnada modificaba el art. 44 del Cód. Civil español relativo al matrimonio ${ }^{119}$, introduciendo la posibilidad de que personas del mismo sexo contraigan matrimonio ${ }^{120}$. El carácter de concepto controvertido es asumido expresamente por el alto Tribunal español cuando señala que «[S] in entrar a valorar en este momento el fondo de los argumentos ofrecidos por el legislador en la exposición de motivos de la norma se puede, en cambio, afirmar que la explicación racional concurre, sin perjuicio de que los recurrentes puedan estar en desacuerdo con la misma» (fundamento jurídico 4).

117 García Salgado (2003). «Determinar lo indeterminado: sobre cláusulas generales y los problemas que plantean». Anuario de Filosofía del Derecho N. ${ }^{\circ} 20,114$.

118 En este sentido conviene recordar lo señalado por Fernández García, en cuanto a que la interpretación de la Constitución por parte del legislador no puede ser resultado de una conducta arbitraria, porque interpretar es una actividad racional. Vid. nota 45.

119 El artículo 44 del Código Civil español disponía que «El hombre y la mujer tienen derecho a contraer matrimonio conforme a las disposiciones de este Código». A su vez, el artículo 32 de la Constitución española dispone que: «1. El hombre y la mujer tienen derecho a contraer matrimonio con plena igualdad jurídica.

2. La ley regulará las formas de matrimonio, la edad y capacidad para contraerlo, los derechos y deberes de los cónyuges, las causas de separación y disolución y sus efectos».

${ }^{120}$ La ley impugnada introducía el siguiente párrafo segundo: «El matrimonio tendrá los mismos requisitos y efectos cuando ambos contrayentes sean del mismo o de diferente sexo». 
El Tribunal Constitucional recurrió al principio de interpretación evolutiva, para dar por sentado que socialmente el concepto mismo de matrimonio habría cambiado, y que por ende la reforma no era inconstitucional ${ }^{121}$. Más aún, el Tribunal sostuvo que la heterosexualidad del matrimonio ya no era un elemento esencial de éste, pues sólo tendrían tal carácter «la igualdad de los cónyuges, la libre voluntad de contraer matrimonio con la persona de la propia elección y la manifestación de esa volunta$\mathrm{d}{ }^{122}$. De esta forma, el Tribunal español modificó el sentido tradicional del concepto de matrimonio, sin perjuicio de que, como ya se dijo, también reconoció que se puede estar en desacuerdo con este nuevo significado.

A su vez, en Colombia también se transformó en concepto controvertido la expresión matrimonio. Pero a diferencia de España, en este caso la transformación ocurrió no por decisión legislativa, sino que por una resolución de la Corte Constitucional colombiana. Así, en ausencia de ley que permitiese el matrimonio entre personas del mismo sexo, la Corte Constitucional procedió a reinterpretar dicho concepto. En su sentencia 214/16 de 28 de abril de 2016, la Corte sostuvo que «la configuración de un concepto jurídico, como es aquel del matrimonio, responde no sólo a la representación de un hecho social, sino que envuelve un conjunto de valores, cargas afectivas y relaciones de poder existentes en una determinada sociedad. Se trata, en consecuencia, de un concepto evolutivo, cuya comprensión ha variado a lo largo de los siglos». A juicio de la Corte, «aquello que los individuos se representan mentalmente cuando se alude a la palabra «matrimonio», dependerá del resultado de unas relaciones de poder, la interacción entre un conjunto de valores culturales y, asimismo, lo socialmente preestablecido y aceptado por las mayorías» (considerando 6). De esta manera, la Corte da a entender en su fallo que en Colombia se habrían dado los supuestos que avalarían darle un nuevo sentido al concepto matrimonio.

Por su parte, en Alemania el Tribunal Constitucional fijó en 2002 una posición respecto del significado del matrimonio, que recientemente ha sido puesta en duda por el legislador. En efecto, en su sentencia de 17 de julio de $2002^{123}$, el Tribunal Constitucional sostuvo que la Constitución «no contiene definición alguna de matrimonio, sino que la presupone, como una forma muy especial de la convivencia humana». Y agregó que si bien «el legislador tiene un amplio margen de configuración para determinar la forma y el contenido del matrimonio», ello es sin perjuicio de que el matrimonio tiene un contenido determinado, entre el que «se encuentra —independientemente del cambio social y de las modificaciones que dicho cambio implica para su configuración jurídica- que éste constituye la unión de un hombre con una mujer, por la que se forma una comunidad de vida con permanencia en el tiempo, fundada sobre una determinación libre y con la intervención del Estado (cf. BVerfGE

121 Ver fundamento jurídico 9 de la sentencia.

122 Ibid.

123 Sentencia $1 \mathrm{BvF}$ 1/01, $1 \mathrm{BvF}$ 2/01, considerando A II., que puede consultarse en Schwabe, J. (2009). Jurisprudencia del Tribunal Constitucional Federal Alemán, Berlin, Konrad Adenauer Stiftung., $265-266$ 
10, 59 [66]; 29, 166 [176]; 62, 323 [330]); en dicha comunidad, hombre y mujer se encuentran en igualdad de derechos y obligaciones respecto uno de otro (cf. BVerfGE 37, 217 [249 ss.]; 103,89 [101]), y ambos determinar libremente la configuración de su vida en común (cf. BVerfGE 39, 169 [183]; 48, 327 [338]; 66, 84 [94]). Lo anterior ha sido reconocido así por la Constitución, la cual a su vez ha modelado la institución jurídica del matrimonio de este modo».

Sin embargo, el 30 de junio de 2017, el Bundestag aprobó una ley que permite el matrimonio entre personas del mismo sexo. Por tal razón, un grupo de parlamentarios anunció la impugnación de la ley, por ir en contra de la Constitución y de lo resuelto por el TC Federal en las decisiones recién mencionadas.

Otro caso de un concepto que hasta hace poco parecía carecer de ambigüedad, es el de sexo. Utilizado habitualmente en el Derecho a propósito del principio de igualdad ante la ley, su significado natural y obvio ha sido el referido a la condición biológica (diferencias en la estructura de cromosomas y en los órganos sexuales), que permite diferenciar entre femenino y masculino. No obstante, en los últimos años se han ido difundiendo las ideas de movimientos que plantean que lo biológico no determinaría necesariamente la identidad sexual de las personas, lo que, entre otras cosas, ha repercutido en el Derecho mediante el surgimiento de conflictos relacionados con esta visión. Y así por ejemplo, en State of Texas et al. V. United States of America $^{124}$, la justicia federal tuvo que pronunciarse sobre la legalidad de una carta ${ }^{125}$ enviada a todas las escuelas que recibían financiación estatal, mediante la cual se disponía que en virtud de una normativa Federal, debía asegurarse que sus alumnos pudieran elegir los baños, camarines y duchas a los que quisieran acceder según su identidad de género, y no de su sexo. El documento advertía que la no adopción de las medidas que permitieran hacerlas efectivas, conduciría a la cancelación de todo financiamiento proveniente de la Unión.

El fundamento de la instrucción contenida en la carta fue una nueva interpretación que se le dio a la expresión sexo, utilizada por la sección 1681a. del Título IX de la Education Amendments de 1972, y por la sección 106.33 del Code of Federal Regulations, transformándola en un concepto controvertido. La primera de esas normas dispone que nadie puede ser excluido en razón de su sexo de los programas o actividades que reciban financiamiento estatal ${ }^{126}$, en tanto que la segunda señala que el

${ }^{124}$ Civil Action No. 7:16-cv-00054-0, District Court for the Northern District of Texas, Wichita Fall Division. Sentencia de 21 de agosto de 2016. La sentencia del caso puede consultarse en https:// www.texasattorneygeneral.gov/files/epress/Texas_et_al_v._U.S._et_al_-_Nationwide_PI_(08-21-16). pdf

125 Formalmente el documento fue calificado como una «Dear Colleague Letter», que en principio, y desde ese punto de vista, no es propiamente un acto administrativo. En tal sentido el caso es también muy interesante, porque el Tribunal tuvo que despejar la duda acerca de la naturaleza de esta Dear Colleague Letter.

126 «No person in the United States shall, on the basis of sex, be excluded from participation in, be denied the benefits of, or be subjected to discrimination under any education program or activity receiving Federal financial assistance». 
beneficiario de financiamiento estatal puede mantener baños, camarines y duchas separados por sexo, en la medida que sus condiciones sean similares para ambos $\operatorname{sexos}^{127}$. En contra de dicha medida varios Estados ${ }^{128}$, y algunas autoridades y entidades de otros Estados, presentaron una acción judicial destinada a impugnar las directrices del Gobierno Federal, basada en que la interpretación de la definición de «sexo» era ilegal, y constituía una amenaza anti-jurídica.

$\mathrm{Al}$ resolver la acción, la Corte sostuvo que las palabras que utilizan las normas deben ser interpretadas según el significado ordinario que éstas tienen, de manera que cuando las palabras no son ambiguas, el juez debe darles aquel sentido ${ }^{129}$. Por el contrario, si las palabras son ambiguas, el juez debe ser deferente frente a las diversas acepciones válidas que puedan deducirse de ellas. Pero a su vez, los diversos significados válidos no son ni pueden ser consecuencia de lo que la sentencia denomina «contorsiones creativas». De esta forma, cuando un término no está definido, los tribunales le darán generalmente su significado común y ordinario, tomando en consideración la intención del legislador ${ }^{130}$. Por eso, a juicio de la Corte el significado del concepto sexo usado en las normas antes mencionadas, es el referido comúnmente a las diferencias bilógicas y anatómicas entre los estudiantes masculinos y femeninos. De ahí entonces que, en su opinión, el concepto no es ambiguo, por lo que la interpretación adoptada por el Gobierno Federal es ilegal.

Más recientemente, en la sentencia del Tribunal Constitucional chileno sobre legalización del aborto (sentencia rol 3729-17), la opinión de cinco de los ministros de este órgano jurisdiccional, transformó en controvertida la expresión "protege», utilizada por el art. 19 N. ${ }^{\circ} 1$ de la Constitución, a propósito del mandato dirigido al legislador con respecto al no nacido ${ }^{131}$. En concreto, la interpretación dada por estos ministros a dicha palabra, hace posible la privación directa de la vida del nasciturus en los supuestos de la ley, lo que en principio no parece compatible con el sentido natural y obvio de aquella ${ }^{132}$.

127 «A recipient may provide separate toilet, locker room, and shower facilities on the basis of sex, but such facilities provided for students of one sex shall be comparable to such facilities provided for students of the other sex».

128 Texas, Alabama, Wisconsin, West Virginia, Tennesse, Oklahoma, Louisiana, Utah, Georgia, Mississippi y Kentucky.

129 La frase utilizada por la sentencia es «[W]hen the words are unambiguous, the "judicial inquiry is complete".»

130 "When a term is not defined, courts may generally give the words their common and ordinary meaning in accordance with legislative intent».

${ }^{131}$ Como se sabe, el inciso $2 .^{\circ}$ del art. 19 N. ${ }^{\circ} 1$ señala: «La ley protege la vida del que está por nacer».

132 Según el diccionario de la Real Academia de la Lengua proteger tiene dos significados, y ninguno de ellos resulta compatible con la posición asumida por estos cinco ministros: «1. tr. Resguardar a una persona, animal o cosa de un perjuicio o peligro, poniéndole algo encima, rodeándolo, etc. U. t. c. prnl.

2. tr. Amparar, favorecer, defender a alguien o algo». Un análisis de la sentencia 3729-17 y de la interpretación dada al art. 19 N..$^{\circ} 1$ inciso $2 .^{\circ}$ de la Constitución puede consultarse en Covarrubias, I. y Martínez, J.I. (2018). «La Ley «protege» la vida del que está por nacer: ¿En qué situación ha quedado el concebido pero no nacido a partir de la sentencia del Tribunal Constitucional?». v.v.a.a Visiones con- 


\section{CONCLUSIONES}

Como se ha señalado a lo largo de este trabajo, los términos que se utilicen en el Derecho pueden muchas veces ser interpretados de manera diversa, y hasta contradictoria, consecuencia de lo que Hart denominó «la textura abierta del derecho», que implica que las normas jurídicas poseen algún grado de abstracción. Por eso es erróneo pensar que la indeterminación se reduce a un determinado tipo de expresiones, las «indeterminadas», sino que es más bien una característica general del lenguaje jurídico. De esta forma, la expresión «conceptos indeterminados» dice relación con la mayor o menor amplitud del significado de los preceptos. En tal sentido, los conceptos indeterminados son aquellos que presentan significados amplios y diversos. Desde este punto de vista, y parafraseando a MacCormick, puede concluirse entonces que en el Derecho existe siempre un cierto «grado aceptable» de indeterminación.

Sin perjuicio de lo anterior, algunos autores plantean que es ventajoso el uso de conceptos indeterminados en los textos constitucionales. En primer lugar, porque su uso permite que las constituciones centren su atención sólo en lo fundamental. En segundo lugar, porque la incorporación de estos conceptos contribuiría a la permanencia y estabilidad del sistema constitucional, al permitir la mejor adaptación del texto constitucional a los cambios de la comunidad política ${ }^{133}$. En tercer lugar, porque las cláusulas indeterminadas podrían servir para resolver la tensión que se produce en temáticas complejas, respecto de las cuales no hay consenso.

La somera revisión de los sistemas constitucionales efectuada en este trabajo, permite formarse una idea de cómo y para qué se usan conceptos abiertos o indeterminados. Así, la Constitución de los Estados Unidos contiene pocos conceptos indeterminados, que han sido interpretados por la Corte Suprema, y también por el Senado. De entre aquéllos destaca en particular la interpretación amplia de las cláusulas de debido proceso e igualdad ante la ley. Asimismo, la Corte Suprema ha descubierto algunos conceptos indeterminados en el texto constitucional, como el de «interés público», «vida privada» $\mathrm{y}$ «dignidad humana». No obstante, en la doctrina norteamericana algunos autores han llamado la atención respecto del riesgo de que estas cláusulas abiertas se transformen en un cheque en blanco, que haría posible un indeseable activismo judicial.

A diferencia de la norteamericana, las constituciones alemana y española cuentan con bastantes conceptos indeterminados. Tanto en Alemania como en España muchos de ellos están relacionados con el ser humano y sus derechos, y con los fines de la comunidad política, y en el caso alemán, con la concepción de los derechos fundamentales como un orden objetivo de valores. Por su parte, en la Constitución espa-

trapuestas sobre el artículo 19 No 1 de la Constitución Política: reflexiones sobre la constitucionalidad de la ley de despenalización del aborto en tres causales, Santiago, Centro de Derechos Humanos, Facultad de Derecho, Universidad Diego Portales, 105-116.

133 Este argumento es compartido por ejemplo por el Tribunal Constitucional chileno. Ver nota 70. 
ñola abundan conceptos indeterminados a propósito del Estado Social y de los derechos sociales. En ambos países la jurisprudencia constitucional ha jugado un rol importante respecto del significado de dichos conceptos. En el caso alemán ha sido especialmente relevante con relación al significado y alcances de la expresión «dignidad humana», lo que es acorde a la relevancia que el propio texto constitucional le otorga a esta expresión. En España se constata además una abundante jurisprudencia constitucional sobre conceptos indeterminados, como «interdicción de la arbitrariedad», «plazo máximo de duración», «plazo de tiempo razonable», «honor», «tutela judicial efectiva», «intereses legítimos», «dilaciones indebidas», «capacidad económica» $\mathrm{y}$ «medio ambiente».

La Constitución de Chile cuenta también con numerosos conceptos indeterminados. Algunos están vinculados con la persona y con su posición en la comunidad política, en tanto que otros están incluidos a propósito de los derechos constitucionales, incluidos los sociales. Asimismo, la Constitución chilena cuenta con conceptos indeterminados relativos al ejercicio de atribuciones especiales de los órganos del Estado, y la doctrina y la jurisprudencia han identificado un concepto no expresamente contenido en el texto constitucional, pero deducido a partir de sus preceptos: el «orden público económico». A éstos deben agregarse los conceptos abiertos contenidos en tratados internacionales ratificados por Chile, que estén vigentes (art. 5 inc. . $^{\circ}$ ), entre los que destacan los contenidos en la Convención Americana de Derechos Humanos, a los que se agrega uno que la Corte Interamericana de D.D.H.H. entiende que está implícito en la Convención, el denominado «control de convencionalidad».

En todo caso, si bien el uso de conceptos indeterminados es en cierta forma inevitable, las peculiaridades del Derecho Constitucional hacen necesario considerar que la existencia que amplios ámbitos de indeterminación, puede acarrear problemas. Esto podría afectar por ejemplo a la seguridad jurídica y a una consecuencia de ésta, la previsibilidad, cuestión que puede resultar especialmente álgida en materias clave como la regulación de los derechos y libertades.

Otra dificultad que plantea el uso de conceptos indeterminados en el lenguaje constitucional, se vincula con el riesgo de alteración de los límites competenciales de cada uno de los poderes del Estado. Este problema puede verse eventualmente acrecentado por la doctrina que entiende a los derechos como un orden objetivo de valores, pues al entenderlos de esta manera se introduce un factor supra-jurídico (filosófico/moral), que necesariamente influirá en la actuación de los órganos estatales, produciéndose dos consecuencias.

La primera dice relación con el hecho de que los conceptos indeterminados deben ser precisados por el legislador y, en su caso, por el ejecutivo, lo que puede conducir a la generación de conflictos interpretativos entre ambos, o entre éstos y los jueces (nacionales y supranacionales). Esto último puede llevar a su vez a un activismo judicial, que podría generar además un injusto cuestionamiento al inherente e indispensable rol de control que le cabe a los jueces en un sistema constitucional. 
Una segunda consecuencia, consiste en que la precisión que los poderes públicos hagan de esos conceptos puede servir de pretexto para camuflar la imposición de valores, percepciones y visiones a través de la creación de normas, o de la interpretación de éstas, dando origen a una especie de ética oficial.

De ahí la necesidad de ser cauto y austero en el uso de conceptos abiertos en las constituciones, a fin de disminuir los riesgos que conlleva generar amplios márgenes de discrecionalidad, propios de la indeterminación. Este cuidado debe extenderse hoy a aquellas formulaciones y expresiones que parecen decirnos mucho más de lo que en verdad dicen, y que aparentan tener un mayor consenso sobre su significado del que realmente tienen, como es el caso de conceptos como «dignidad humana» o «bien común». Este fenómeno afecta también en la actualidad a conceptos que durante siglos habían sido entendidos de una determinada manera, como por ejemplo los de matrimonio o sexo, que, junto a los anteriores, y probablemente debido a visiones constructivistas, han pasado a ser lo que Gallie denomina «conceptos controvertidos».

Como se comprenderá, todo esto puede hacer que el lenguaje utilizado por una norma llegue a carecer absolutamente de relevancia, debido a que el intérprete puede darle el significado que él determine, con independencia de que haya tenido uno claro e indubitado. Aquello puede llevarnos a un escenario alejado de la exigencia de razonabilidad del Derecho, afectándose con ello las legítimas expectativas y la seguridad jurídica.

Title:

Undetermined concepts in the constitutional language.

\section{Summary:}

I. Introduction: Undetermined concepts. II. Undetermined concepts in some constitutional systems: United States, Germany, Spain and Chile. III. Difficulties involved in the use of undetermined concepts in Constitutional Law. IV. A new problem: From concepts determined to controversial concepts. V. Conclusions.

\section{Resumen:}

En este trabajo se analiza el rol que ocupan los conceptos indeterminados o abiertos en el Derecho Constitucional. Para tal efecto se revisan las constituciones de Estados Unidos, Alemania, España y Chile, y se hace una somera revisión de lo que la literatura jurídica 
ha dicho sobre la incorporación de esta clase de cláusulas en esos sistemas constitucionales. Asimismo, se plantean y analizan las consecuencias y riesgos que implican el uso de estos conceptos, y se revisa el problema adicional que surge a partir de la transformación de conceptos ciertos y determinados, en conceptos controvertidos.

\begin{abstract}
:
In this paper it is analyzes the role played by indeterminate or open concepts in Constitutional Law. For this purpose, it have been analyzed the constitutions of the United States, Germany, Spain and Chile, and it is made a brief review about what the legal literature has said concerning the incorporation of this class of clauses in those constitutional systems. Likewise, the paper analyzed the consequences and risks involved in the use of these concepts, and the additional problem arising from the transformation of certain and determined concepts into controversial concepts.
\end{abstract}

Palabras clave:

Conceptos indeterminados; conceptos controvertidos.

Key words:

Undetermined concepts; controversial concepts. 